NBER WORKING PAPER SERIES

\title{
EXTERNAL CONSTRAINTS ON MONETARY POLICY AND THE FINANCIAL ACCELERATOR
}

\author{
Mark Gertler \\ Simon Gilchrist \\ Fabio Natalucci \\ Working Paper 10128 \\ http://www.nber.org/papers/w10128 \\ NATIONAL BUREAU OF ECONOMIC RESEARCH \\ 1050 Massachusetts Avenue \\ Cambridge, MA 02138 \\ December 2003
}

The views in this paper are solely the responsibility of the authors and should not be interpreted as reflecting the views of the Board of Governors of the Federal Reserve System or of any other person associated with the Federal Reserve System. We thank Philippe Bacchetta, Ricardo Caballero, V.V. Chari, and Philip Lowe, as well as participants at the BIS conference on "Monetary stability, financial stability, and the business cycle" The views expressed herein are those of the authors and not necessarily those of the National Bureau of Economic Research.

(C)2003 by Mark Gertler, Simon Gilchrist, and Fabio Natalucci. All rights reserved. Short sections of text, not to exceed two paragraphs, may be quoted without explicit permission provided that full credit, including (C) notice, is given to the source. 
External Constraints on Monetary Policy and the Financial Accelerator

Mark Gertler, Simon Gilchrist, and Fabio Natalucci

NBER Working Paper No. 10128

December 2003

JEL No. E5, F3, F4

\begin{abstract}
We develop a small open economy macroeconomic model where financial conditions influence aggregate behavior. We use this model to explore the connection between the exchange rate regime and financial distress. We show that fixed exchange rates exacerbate financial crises by tieing the hands of the monetary authorities. We then investigate the quantitative significance by first calibrating the model to Korean data and then showing that it does a reasonably good job of matching the Korean experience during its recent financial crisis. In particular, the model accounts well for the sharp increase in lending rates and the large drop in output, investment and productivity during the 1997-1998 episode. We then perform some counterfactual exercises to illustrate the quantitative significance of fixed versus floating rates both for macroeconomic performance and for welfare. Overall, these exercises imply that welfare losses following a financial crisis are significantly larger under fixed exchange rates relative to flexible exchange rates.

Mark Gertler

Department of Economics

New York University

269 Mercer Street, 7th Floor

New York, NY 10003

and NBER

mark.gertler@nyu.edu

Fabio Natalucci

Board of Governors of the Federal Reserve System fabio.m.natalucci@frb.gov
\end{abstract}

Simon Gilchrist

Department of Economics

Boston University

270 Bay State Road

Boston, MA 02215

and NBER

sgilchri@bu.edu 


\section{Introduction}

Over the past twenty years there has been a dramatic rise in the frequency of financial crises that have led to significant contractions in economic activity. One feature of these crises, that pertains in particular to open economies, is the strong connection with a fixed exchange rate regime. In a study covering the 1970s through the 1990s, Kaminsky and Reinhart [30] document the strong correlation between domestic financial strains and currency crises. Put differently, countries in the position of having to defend an exchange rate peg were more likely to have suffered severe financial distress. The likely reason is straightforward: defending an exchange rate peg generally requires the central bank to adjust interest rates in a direction that reinforces the crisis. Moreover, this connection between external constraints on monetary policy and financial crises is not simply a post-war phenomenon: during the Great Depression, as Eichengreen [24] and others have shown, countries that stayed on the gold standard suffered far more severe financial and economic distress than countries that left early.

In this paper we develop a small open economy macroeconomic model where financial conditions influence aggregate behavior. Our goal is to explore the connection between the exchange rate regime and financial distress. Specifically, we extend to the open economy the financial accelerator framework developed in Bernanke, Gertler and Gilchrist [7] (hereafter BGG), that is in turn based on earlier work by Bernanke and Gertler [6], Kiyotaki and Moore [31], Carlstrom and Fuerst [13] and others. We then consider how the choice of the exchange rate regime influences an economy's response to a financial crisis.

To judge the empirical relevance of our framework, we conduct a quantitative exercise aimed at replicating the key features of the Korean experience during the Asian financial crisis of 1997-98. We focus on the Korean episode because it is symptomatic of many financial crises that have occurred over time: the country experienced a sharp contraction in both output and measured productivity, along with a sharp deterioration in credit conditions, including falling asset prices and increasing credit spreads. As well, in the process the country's central bank was attempting to defend a fixed exchange rate regime.

Our quantitative model is able to account for the roughly fourteen percent drop in Korean output during the 1997-98 crisis, as well as most of the other salient features of this

episode. The financial accelerator mechanism is key: we show that it accounts for nearly half of the decline in economic activity. We also perform some counterfactual exercises to 
illustrate how being tied to the fixed exchange rate regime may have exacerbated the crisis. Because our model is optimization-based, we are able to compute the explicit welfare costs of the crisis and explore the welfare consequences of pursuing alternative policies.

Several papers have recently emphasized that sharp declines in measured productivity are a robust characteristic of financial crises, raising the possibility that productivity shocks (broadly defined) may be the true underlying causal force (e.g., Cole and Ohanian [21] and Chari, Kehoe and McGrattan [16]). We demonstrate, however, that it is possible to explain most of the variation in measured productivity during the Korean crisis by appealing to endogenous utilization of capital. Specifically, within our model, the investment and output collapse brought about by the financial crisis induces a drop in capital utilization, leading to a decline in measured productivity. Of course, in this case the drop in productivity reflects mismeasurement of capital input utilization and not a true shift in productivity. To support this modelling approach, we present evidence that electricity utilization (a conventional proxy for capital utilization) fell sharply in tandem with measured productivity.

Finally, we note that there is now a lengthy literature containing theoretical models of financial crises in emerging market economies. Our paper is in the spirit of a large subset of this literature that emphasizes how balance sheets on borrower spending (arising from credit market frictions) give rise to a financial accelerator mechanism that works to propagate financial crises. Some prominent examples include: Aghion, Bacchetta, and Banerjee [2], Cespedes, Chang and Velasco [14] (hereafter CCV), Caballero and Krisnamurthy [11], Christiano, Gust and Roldos [17], Devereux and Lane [23], and Schneider and Tornell [40]. Our paper is probably closest to CCV, who similarly emphasize the role of the exchange rate policy. The analysis in virtually all of this literature, however, is focused on qualitative results. In contrast, we develop a quantitative model and then explore how well the model can account for an actual crisis experience. ${ }^{2}$

The rest of the paper is organized as follows. Section 2 describes the Korean experience and presents evidence on a set of key macroeconomic variables. Section 3 introduces the model. Section 4 first presents some policy experiments to illustrate the interaction between the financial accelerator and the exchange rate regime. It then presents an exercise to assess how well the model can capture the Korean experience, along with several counterfactual policy experiments. Section 5 provides concluding remarks.

\footnotetext{
${ }^{2}$ Christiano, Gust and Roldos (2002) also perform a quantitative analysis, though they focus on explaining the implications for monetary transmission in a crisis, as opposed to matching model performance against an actual crisis experience.
} 


\section{The Korean Financial Crisis}

The Korean financial crisis began in October of 1997, following crises in Thailand and other Asian countries that had unfolded few months earlier. Even though it was not the first in a chain, the Korean crisis was largely unanticipated, according to Krueger and Yoo [33]. Although Korean banks were heavily exposed to risk in emerging market economies, this was not widely appreciated until October 1997 when Standard \& Poors downgraded the country's sovereign risk status. ${ }^{3}$ Massive capital flight along with a sharp rise in the country risk premium followed. Dwindling foreign currency reserves then forced the central bank to raise the overnight call rate over a thousand basis points. The sharp rise in the country risk premium and short-term interest rates was the prelude to a substantial deterioration of real economic activity.

Figure 1 plots the real-side behavior of the Korean economy during this time period. Real GDP had been consistently above trend for several years before the crisis and showed no weakness until the fourth quarter of 1997. During the first quarter of 1998, real GDP fell eight percent and subsequently contracted by another six percent. Investment played a key role in the overall decline. Real gross capital formation had been gradually weakening since the beginning of 1997 and then experienced a forty percent contraction in the first quarter of 1998, before falling another ten percent in the subsequent two quarters. Real consumption spending tracked GDP during the downturn, falling by fourteen percent in the first quarter of 1998 and eighteen percent overall during the crisis period. Employment fell by somewhat less than GDP - eight percent from peak to trough, implying a six percent reduction in labor productivity, as measured by GDP per worker. The drop in labor productivity is associated with a sharp reduction in capital utilization over this time period, using electricity consumption as a proxy for capital services. ${ }^{4}$

Figure 2 plots the behavior of various financial variables. As we noted earlier, the country borrowing premium, as measured by the EMBI Global spread, rose five hundred basis points (from one hundred to six hundred) in a two-month period following the onset

\footnotetext{
${ }^{3}$ In particular, Korean off-shore banks held substantial quantities of dollar-denominated foreign loans from countries such as Indonesia and Russia.

${ }^{4}$ If energy and capital services enter the production function as perfect complements owing to a Leontief technology, then electricity is a perfect measure for capital utilization. Econometric estimates imply a very low degree of substitutability between capital and energy especially in the short-run, making electricity a very good proxy even in the absence of perfect complementarity.
} 
of the crisis in October 1997. ${ }^{5}$ The central bank's attempt to defend the exchange rate led to an increase in the overnight call rate of twelve hundred basis points in the final quarter of 1997. Associated with the sharp increase in the country risk premium and the call rate was a substantial rise in credit spreads, together with a substantial decline in asset prices. The corporate-treasury bond spread rose nine percentage points. The stock market, which had been trending downward prior to the crisis, lost two hundred points, or a third of its value, in the immediate aftermath of the crisis. Following a brief rally, stock prices lost another hundred points before beginning a recovery in the second quarter of 1998.

Once the central bank abandoned the peg in favor of a flexible exchange rate, interest rates were gradually reduced in 1998. It is reasonable to believe that prior expectations regarding the probability that Korea would abandon the fixed exchange rate were low. ${ }^{6}$ Once it was clear that the Bank of Korea failed in its attempt to defend the won, however, the currency depreciated by almost fifty percent. Inflation, which was averaging four percent before the crisis, increased five percentage points in the first quarter of 1998 as import prices rose sharply following the devaluation. The overall reduction in economic activity led to a sharp contraction in inflation however. By the first quarter of 1999, inflation had fallen to half percent, well below its pre-crisis level.

Figure 3 plots the foreign sector of the Korean economy. The forty percent decline in the real exchange rate led to a fifteen percent increase in the ratio of net exports to GDP. Nearly all of this increase in net exports is attributable to the forty percent decline in imports rather than an expansion in exports however. Thus it appears that the competitiveness effect of the devaluation had, at best, only a modest expansionary effect on the economy. ${ }^{7}$

In sum, the initial stages of the Korean crisis were associated with an unanticipated large outflow of capital and a simultaneous increase in the country borrowing premium. Shortterm interest rates rose rapidly because the central bank was attempting to defend a fixed exchange rate. In the months that followed, both financial and real conditions deteriorated sharply. Eventually the economy recovered, though only after the central bank had clearly

\footnotetext{
${ }^{5}$ The country risk spread also rose sharply following the Russian crisis. This had very little effect on the Korean economy however. By this time, the Korean monetary authority had abandoned the fixed exchange rate regime.

${ }^{6}$ Even though Thailand, after a strong speculative attack, let the currency float on July 2, 1997, the EMBI Global for Korea climbed above hundred basis points only on October 9, 1997.

${ }^{7}$ This reflects, in part, the fact that many of Korea's Asian trading partners were also suffering from the crisis environment. It also reflects the fact that the Korean economy was unable to grow its way out of the recession by exporting more goods to economically stable trading partners such as the U.S and Europe.
} 
abandoned the peg. We next proceed to develop a quantitative model designed to capture these phenomena.

\section{The Model}

The core framework is a small open economy model with money and nominal price rigidities, along the lines of Obstfeld and Rogoff [37], Svensson [41], Gali and Monacelli [28], Chari, Kehoe and McGrattan [15], and others. The key modification is the inclusion of a financial accelerator mechanism, as developed in BGG. The financial accelerator mechanism links the condition of borrower balance sheets to the terms of credit, and hence to the demand for capital. Via the impact on borrower balance sheets, the financial accelerator magnifies the effects of shocks to the economy. As in Kiyotaki and Moore [31] and BGG, unanticipated movements in asset prices provide the main source of variation in borrower balance sheets. As in BGG, a countercyclical monetary policy can potentially mitigate a financial crisis: easing of rates during a contraction, for example, helps stabilize asset price movements and hence borrower balance sheets. External constraints on monetary policy, instead, limit this stabilizing option.

Within the model there exist both households and firms. There is also a foreign sector and a government sector. Households work, save, and consume tradable goods that are produced both at home $(\mathrm{H})$ and abroad $(\mathrm{F})$. Domestically and foreign-made goods are imperfect substitutes.

Within the home country, there are three types of producers: (i) entrepreneurs; (ii) capital producers; and (iii) retailers. Entrepreneurs manage the production of wholesale goods. They borrow from households to finance the acquisition of capital used in the production process. Due to imperfections in the capital market, entrepreneurs' demand for capital depends on their respective financial positions - this is the key aspect of the financial accelerator. In turn, in response to entrepreneurial demand, capital producers build new capital. Finally, retailers package together wholesale goods to produce final output. They are monopolistically competitive and set nominal prices on a staggered basis. The role of the retail sector in our model is simply to provide the source of nominal price stickiness.

We now proceed to describe the behavior of the different sectors of the economy, along with the key resource constraints. 


\subsection{Households}

\subsubsection{Consumption Composites}

Let $C_{t}$ be a composite of tradable consumption goods. Then the following CES index defines household preferences over home consumption, $C_{t}^{H}$, and foreign consumption, $C_{t}^{F}$ :

$$
C_{t}=\left[(\gamma)^{\frac{1}{\rho}}\left(C_{t}^{H}\right)^{\frac{\rho-1}{\rho}}+(1-\gamma)^{\frac{1}{\rho}}\left(C_{t}^{F}\right)^{\frac{\rho-1}{\rho}}\right]^{\frac{\rho}{\rho-1}}
$$

The corresponding consumer price index $(\mathrm{CPI}), P_{t}$ is given by

$$
P_{t}=\left[(\gamma)\left(P_{t}^{H}\right)^{1-\rho}+(1-\gamma)\left(P_{t}^{F}\right)^{1-\rho}\right]^{\frac{1}{1-\rho}}
$$

The domestic consumption good, $C_{t}^{H}$, is a composite of differentiated products sold by domestic monopolistically competitive retailers. However, since we can describe household behavior in terms of the composite good $C_{t}^{H}$, we defer discussion of the retail sector until section (3.3.3) below.

\subsubsection{The Household's Decision Problem}

Let $H_{t}$ denote household labor and $M_{t} / P_{t}$ denote real money balances. Household preferences are given by

$$
E_{0} \sum_{t=0}^{\infty} \beta^{t} U\left(C_{t}, H_{t}, \frac{M_{t}}{P_{t}}\right)
$$

with

$$
U\left(C_{t}, H_{t}, \frac{M_{t}}{P_{t}}\right)=\frac{\left[\left(C_{t}\right)^{1-\varsigma}\left(1-H_{t}\right)^{\varsigma}\right]^{1-\sigma}}{1-\sigma}+\xi \log \left(\frac{M_{t}}{P_{t}}\right)
$$

and with $\sigma \geq 0, \varsigma \in(0,1)$, and $\xi>0$.

Let $W_{t}$ denote the nominal wage; $\Pi_{t}$ real dividend payments (from ownership of retail firms); $T_{t}$ lump sum real tax payments; $S_{t}$ the nominal exchange rate; $B_{t+1}$ and $B_{t+1}^{*}$ nominal bonds denominated in domestic and foreign currency, respectively; and $\left(1+i_{t}\right)$ and $\left(1+i_{t}^{*}\right)$ the domestic and foreign gross nominal interest rate, respectively. In addition, $\Psi_{t}$ represents a gross borrowing premium that domestic residents must pay to obtain funds from abroad. The household's budget constraint is then given by

$$
C_{t}=\frac{W_{t}}{P_{t}} H_{t}+\Pi_{t}-T_{t}-\frac{M_{t}-M_{t-1}}{P_{t}}-\frac{B_{t+1}-\left(1+i_{t-1}\right) B_{t}}{P_{t}}-\frac{S_{t} B_{t+1}^{*}-S_{t} \Psi_{t}\left(1+i_{t-1}^{*}\right) B_{t}^{*}}{P_{t}}
$$


where $\Psi_{t}$, the country borrowing premium, depends on total net foreign indebtedness, $N F_{t}$, and a random shock, $\Phi_{t}$, as follows: $\Psi_{t}=f\left(N F_{t}\right) \Phi_{t}$, with $f^{\prime}(\cdot)>0$. We introduce this country borrowing premium partly for technical reasons. Without it, net foreign indebtedness may be non-stationary, complicating the analysis of local dynamics. Thus, following Schmitt-Grohe and Uribe [39] we introduce a small friction in the world capital market. We set the elasticity of $\Psi_{t}$ with respect to $N F_{t}$ very close to zero, so that this distortion does not alter the high frequency model dynamics but nonetheless makes $N F_{t}$ revert to trend. A second important reason for introducing the country borrowing premium $\Psi_{t}$ is that it is a simple way to model sudden capital outflows of the type that appeared to initiate the Korean crisis, as described in the previous section. In particular, we represent a sudden capital outflow as a positive blip in the random variable $\Phi_{t}$, which in turn directly raises $\Psi_{t}$.

The household maximizes (3) subject to (4) and (5).

\subsubsection{Consumption Allocation, Labor Supply, and Saving}

The optimality conditions for the consumption allocation, labor supply, and the consumption/saving decision are reasonably conventional:

$$
\begin{gathered}
\frac{C_{t}^{H}}{C_{t}^{F}}=\frac{\gamma}{1-\gamma}\left(\frac{P_{t}^{H}}{P_{t}^{F}}\right)^{-\rho} \\
(1-\varsigma) \frac{1}{C_{t}} \frac{W_{t}}{P_{t}}=\varsigma \frac{1}{1-H_{t}} \\
\lambda_{t}=\beta E_{t}\left\{\lambda_{t+1}\left(1+i_{t}\right) \frac{P_{t}}{P_{t+1}}\right\}
\end{gathered}
$$

where $\lambda_{t}$, the marginal utility of the consumption index, is given by

$$
\lambda_{t}=(1-\varsigma)\left(C_{t}\right)^{(\sigma-1)(\varsigma-1)-1}\left(1-H_{t}\right)^{\varsigma(1-\sigma)}
$$

and $\left(1+i_{t}\right) \frac{P_{t}}{P_{t+1}}$ denotes the gross real interest rate. In addition, the optimality condition governing the choice of foreign bonds in conjunction with equation (8) yields the following uncovered interest parity condition:

$$
E_{t}\left\{\lambda_{t+1} \frac{P_{t}}{P_{t+1}}\left[\left(1+i_{t}\right)-\Psi_{t}\left(1+i_{t}^{*}\right) \frac{S_{t+1}}{S_{t}}\right]\right\}=0 .
$$


The household also decides money holdings. However, we do not report this relation in the model. Because we restrict attention to monetary regimes where either the nominal exchange rate or the nominal interest rate is the policy instrument, money demand plays no role other than to pin down the nominal money stock (see, e.g., Clarida, Gali and Gertler $[18])$.

\subsection{Foreign Behavior}

In considering arbitrage in goods markets, we distinguish between the wholesale (import) price of foreign goods and the retail price in the domestic market by allowing for imperfect competition and pricing-to-market in the local economy (see section 3.3.3). At the wholesale level, the law of one price holds. Let $P_{W, t}^{F}$ denote the wholesale price of foreign goods in domestic currency, and $P_{t}^{F *}$ the foreign currency price of such goods. The law of one price then implies:

$$
P_{W, t}^{F}=S_{t} P_{t}^{F *}
$$

We take as exogenous both the gross foreign nominal interest rate $\left(1+i_{t}^{*}\right)$ and the nominal price (in units of foreign currency) of the foreign tradable good, $P_{t}^{F *}$. Finally, we assume that foreign demand for the home tradable good, $C_{t}^{H^{*}}$, is given by

$$
C_{t}^{H^{*}}=\left[\left(\frac{P_{t}^{H *}}{P_{t}^{*}}\right)^{-\varkappa} Y_{t}^{*}\right]^{\nu}\left(C_{t-1}^{H^{*}}\right)^{1-\nu}, 0 \leq \nu \leq 1
$$

where $Y_{t}^{*}$ is real foreign output, which we take as given. The term $\left(C_{t-1}^{H^{*}}\right)^{1-\nu}$ represents inertia in foreign demand for domestic products. Because the home economy is small (in the sense that it cannot affect foreign output, the foreign price level, or the foreign interest rate), it is sensible to simply postulate an empirically reasonable reduced-form export demand curve.

In addition, we assume balanced trade in the steady state and normalize the steady terms of trade at unity.

\section{$3.3 \quad$ Firms}

We consider in turn: entrepreneurs, capital producers, and retailers.

\subsubsection{Entrepreneurs, Finance, and Wholesale Production}

Entrepreneurs manage production and obtain financing for the capital employed in the production process. Entrepreneurs are risk neutral. To ensure that they never accumulate 
enough funds to fully self-finance their capital acquisitions, we assume they have a finite expected horizon. Each survives until the next period with probability $\phi$. Accordingly, the expected horizon is $\frac{1}{1-\phi}$. The entrepreneurs' population is stationary, with new entrepreneurs entering to replace those who exit. To ensure that new entrepreneurs have some funds available when starting out, we follow BGG by endowing each entrepreneur with $H_{t}^{e}$ units of labor which is supplied inelastically as a managerial input to production. Entrepreneurs receive a small wage in compensation.

The entrepreneur starts any period $t$ with capital, $K_{t}$, acquired in the previous period (shortly we describe the capital acquisition decision.) He then produces domestic output, $Y_{t}$, using labor, $L_{t}$, and capital services, $u_{t} K_{t}$, where $u_{t}$ is the capital utilization rate. (For notational simplicity we omit entrepreneur-specific indices.) The labor input $L_{t}$ is assumed to be a composite of household and managerial labor: $L_{t}=H_{t}^{\Omega} H_{t}^{e(1-\Omega)}$. We normalize $H_{t}^{e}$ to unity. The entrepreneur's gross project output, $G Y_{t}$, consists of the sum of his production revenues and the market value of his remaining capital stock. In addition, we assume his project is subject to an idiosyncratic shock, $\omega_{t}$, that affects both the production of new goods and the effective quantity of his capital. The shock $\omega_{t}$ may be considered a measure of the quality of his overall capital investment.

Let $P_{W, t}$ be the nominal price of wholesale output, $Q_{t}$ the real market price of capital, ${ }^{8}$ $P_{I, t}$ the nominal replacement price of capital (see section 3.3.2), $\delta_{t}$ the depreciation rate, and $A_{t}$ a common productivity factor. Then, by definition, $G Y_{t}$, equals the sum of output revenues, $\frac{P_{W, t}}{P_{t}} Y_{t}$, and the market value of the capital stock, $Q_{t} \omega_{t} K_{t}$, net of the cost of repairing the worn out equipment, $\frac{P_{I, t}}{P_{t}} \delta_{t} \omega_{t} K_{t}$ :

$$
G Y_{t} \equiv \frac{P_{W, t}}{P_{t}} Y_{t}+\left(Q_{t}-\frac{P_{I, t}}{P_{t}} \delta_{t}\right) \omega_{t} K_{t}
$$

where wholesale good production, $Y_{t}$, is given by

$$
Y_{t}=\omega_{t} A_{t}\left(u_{t} K_{t}\right)^{\alpha} L_{t}^{1-\alpha}
$$

Note that the entrepreneur has the option of either selling his end-of-period capital on the market or keeping it for use in the subsequent period. Finally, we assume that $\omega_{t}$ is an i.i.d random variable, distributed continuously with mean equal to one, i.e. $E\left\{\omega_{t}\right\}=1$.

\footnotetext{
${ }^{8} Q_{t}$ is in units of the household consumption index (1).
} 
Following Greenwood, Hercowitz and Huffman [29], we endogenize the utilization decision by assuming that the capital depreciation rate is increasing in $u_{t}$. As in Baxter and Farr [5], depreciation is the following convex function $\delta_{t}(\cdot)$ of the utilization rate:

$$
\delta\left(u_{t}\right)=\delta+\frac{b}{1+\xi}\left(u_{t}\right)^{1+\xi} \quad \text { with } \delta, b, \xi>0 .
$$

At time $t$, the entrepreneur chooses labor and the capital utilization rate to maximize profits, conditional on $K_{t}, A_{t}$ and $\omega_{t}$. Accordingly, labor demand satisfies

$$
\begin{aligned}
(1-\alpha) \Omega \frac{Y_{t}}{H_{t}} & =\frac{W_{t}}{P_{W, t}} \\
(1-\alpha)(1-\Omega) \frac{Y_{t}}{H_{t}^{e}} & =\frac{W_{t}^{e}}{P_{W, t}}
\end{aligned}
$$

where $W_{t}^{e}$ is the managerial wage. The optimality condition for capital utilization is

$$
\alpha \frac{Y_{t}}{u_{t}}=\delta^{\prime}\left(u_{t}\right) K_{t} \frac{P_{I, t}}{P_{W, t}} .
$$

Equation (17) equates the marginal value of the output gain from a higher rate of utilization with its marginal cost owing to a higher rate of capital depreciation.

We now consider the capital acquisition decision. At the end of period $t$, the entrepreneur purchases capital which can be used in the subsequent period $t+1$ to produce output at that time. The entrepreneur finances the acquisition of capital partly with his own net worth available at the end of period $t, N_{t+1}$, and partly by issuing nominal bonds, $B_{t+1}$. Then capital financing is divided between net worth and debt, as follows:

$$
Q_{t} K_{t+1}=N_{t+1}+\frac{B_{t+1}}{P_{t}}
$$

The entrepreneur's net worth is essentially the equity of the firm, i.e., the gross value of capital net of debt, $Q_{t} K_{t+1}-\frac{B_{t+1}}{P_{t}}$. The entrepreneur accumulates net worth through past earnings, including capital gains. We assume that new equity issues are prohibitively expensive, so that all marginal finance is obtained through debt. ${ }^{9}$ We also assume that debt is denominated in units of domestic currency. Later we will consider the case where debt is issued in foreign currency units.

\footnotetext{
${ }^{9}$ To be clear, being an equity holder in this context means being privy to the firm's private information, as well as having a claim on the earnings stream. Thus, we are assuming that the firm cannot attract new wealthy investors that costlessly absorb all firm-specific information.
} 
The entrepreneur's demand for capital depends on the expected marginal return and the expected marginal financing cost. The marginal return to capital (equal to the expected average return due to constant returns) is next period's ex-post gross output net of labor costs, normalized by the period $t$ market value of capital:

$$
\begin{aligned}
1+r_{t+1}^{k} & =\frac{G Y_{t+1}-\frac{W_{t+1}}{P_{t+1}} L_{t+1}}{Q_{t} K_{t+1}} \\
& =\frac{\omega_{t+1}\left[\frac{P_{W, t+1}}{P_{t+1}} \alpha \frac{\bar{Y}_{t+1}}{K_{t+1}}-\frac{P_{I, t+1}}{P_{t+1}} \delta\left(u_{t+1}\right)+Q_{t+1}\right]}{Q_{t}}
\end{aligned}
$$

where $\bar{Y}_{t+1}$ is the average level of output per entrepreneur (i.e., $Y_{t+1}=\omega_{t} \bar{Y}_{t+1}$ ). Note that the marginal return varies proportionately with the idiosyncractic shock $\omega_{t+1}$. Since $E_{t}\left\{\omega_{t+1}\right\}=1$, we can express the expected marginal return simply as

$$
E_{t}\left\{1+r_{t+1}^{k}\right\}=\frac{E_{t}\left\{\frac{P_{W, t+1}}{P_{t+1}} \alpha \frac{\bar{Y}_{t+1}}{K_{t+1}}-\frac{P_{I, t+1}}{P_{t+1}} \delta\left(u_{t+1}\right)+Q_{t+1}\right\}}{Q_{t}} .
$$

The marginal cost of funds to the entrepreneur depends on financial conditions. We postulate an agency problem that makes uncollateralized external finance more expensive than internal finance. As in BGG, we assume a costly state verification problem. The idiosyncratic shock $\omega_{t}$ is private information for the entrepreneur, implying that the lender cannot freely observe the project's gross output. To observe this return, the lender must pay an auditing cost - interpretable as a bankruptcy cost - that is a fixed proportion $\mu_{b}$ of the project's ex-post gross payoff, $\left(1+r_{t+1}^{k}\right) Q_{t} K_{t+1}$. The entrepreneur and the lender negotiate a financial contract that: (i) induces the entrepreneur not to misrepresent his earnings; and (ii) minimizes the expected deadweight agency costs (in this case the expected auditing costs) associated with this financial transaction.

We restrict attention to financial contracts that are negotiated one period at a time and that offers lenders a payoff that is independent of aggregate risk. As we show in the appendix, under these assumptions it is straightforward to show that the optimal contract takes a very simple and realistic form: standard debt with costly bankruptcy. If the entrepreneur does not default, the lender receives a flat payment. If the entrepreneur defaults, the lender audits and seizes whatever it finds. It is true that we are arbitrarily ruling out the possibility of enterpreneurs obtaining insurance against aggregate risks to their net worth. However, some experiments that we do not report here suggest that the households in our 
framework are too risk averse to be willing to provide this insurance, at least given our model parametrization. ${ }^{10}$ In general, though, we simply appeal to realism and features outside the model (e.g. difficulties in enforcing wealth transfers in bad times) to rule out aggregate state-contingent wealth insurance. ${ }^{11}$

Overall, the agency problem implies that the opportunity cost of external finance is more expensive than that of internal finance. Because the lender must receive a competitive return, it charges the borrower a premium to cover the expected bankruptcy costs. Because the external finance premium affects the overall cost of finance, it therefore influences the entrepreneur's demand for capital.

In general, the external finance premium varies inversely with the entreprenuer's net worth: the greater the share of capital that the entrepreneur can either self-finance or finance with collateralized debt, the smaller the expected bankruptcy costs and, hence, the smaller the external finance premium. Rather than present the details of the agency problem here, we simply observe, following BGG, that the external finance premium, $\chi_{t}(\cdot)$, may be expressed as an increasing function of the leverage ratio, $\frac{\frac{B_{t+1}}{P_{t}}}{N_{t+1}}$ :

$$
\begin{aligned}
& \chi_{t}(\cdot)=\chi\left(\frac{\frac{B_{t+1}}{P_{t}}}{N_{t+1}}\right) \\
& \chi^{\prime}(\cdot)>0, \chi(0)=0, \chi(\infty)=\infty .
\end{aligned}
$$

The specific form of $\chi_{t}(\cdot)$ depends on the primitive parameters of the costly state verification problem, including the proportional bankruptcy cost $\mu_{b}$ and the distribution of the idiosyncratic shock $\omega_{t}$ (see the appendix for details.) In addition, note that $\chi_{t}(\cdot)$ depends only on the aggregate leverage ratio and not on any entrepreneur-specific variables. This

\footnotetext{
${ }^{10}$ Specifically, in the model experiments we consider below, we compared the percent variation in the shadow value of a unit of wealth for entrepreneurs versus households. For entrepreneurs, this shadow value corresponds to the discounted value of the change in profits that stem from having another unit of wealth. It varies countercyclically because credit constraints vary countercyclically. For households, this shadow value corresponds to the marginal utility of consumption. Each household's shadow value also varies countercyclically since consumption is procyclical. Our computational experiments suggested that, for the financial crisis we simulate below, the percent increase in household's marginal utility of consumption exceeded the percent rise in the entrepreneurs' shadow value of wealth. These results suggest that, at least for the parametrizations used here, households would not be willing to insure enterpreneurs against the kind aggregate risks that lead to crises.

${ }^{11}$ Krishnamurthy [32], for example, motivates incomplete wealth insurance against aggregate risk by appealing to credibility problems on the part of the supplier.
} 
simplification arises because, in equilibrium, all entrepreneurs choose the same leverage ratio, which owes to having constant returns in both production and bankruptcy costs due to risk neutrality (see, e,g. Carlstrom and Fuerst [13] and BGG.)

By definition, the entrepreneur's overall marginal cost of funds in this environment is the product of the gross premium for external funds and the gross real opportunity cost of funds that would arise in the absence of capital market frictions. Accordingly, the entrepreneur's demand for capital satisfies the optimality condition

$$
E_{t}\left\{1+r_{t+1}^{k}\right\}=\left(1+\chi_{t}(\cdot)\right) E_{t}\left\{\left(1+i_{t}\right) \frac{P_{t}}{P_{t+1}}\right\}
$$

where $E_{t}\left\{\left(1+i_{t}\right) \frac{P_{t}}{P_{t+1}}\right\}$ is the gross cost of funds absent capital market frictions.

Equation (22) is interpretable as follows: at the margin, the entrepreneur considers acquiring a unit of capital financed by debt. The additional debt, however, raises the leverage ratio, increasing the external finance premium and the overall marginal cost of finance. Relative to perfect capital markets, accordingly, the demand for capital is lower, the exact amount depending on $\chi_{t}(\cdot) \cdot{ }^{12}$

Equation (22) provides the basis for the financial accelerator. It links movements in the borrower financial position to the marginal cost of funds and, hence, to the demand for capital. Note, in particular, that fluctuations in the price of capital, $Q_{t}$, may have significant effects on the leverage ratio, $\frac{\frac{B_{t+1}}{P_{t}}}{N_{t+1}}=\frac{\frac{B_{t+1}}{P_{t}}}{Q_{t} K_{t+1}-\frac{B_{t+1}}{P_{t}}}$. In this way, the model captures the link between asset price movements and collaterals stressed in the Kiyotaki and Moore [31] theory of credit cycles.

The other key component of the financial accelerator is the relation that describes the evolution of entrepreneurial net worth, $N_{t+1}$. Let $V_{t}$ denote the value of entrepreneurial firm capital net of borrowing costs carried over from the previous period. This value is given by

$$
V_{t}=\left(1+r_{t}^{k}\right) Q_{t-1} K_{t}-\left[(1+\chi(\cdot))\left(1+i_{t-1}\right) \frac{P_{t-1}}{P_{t}}\right] \frac{B_{t}}{P_{t-1}}
$$

In this expression, $\left(1+r_{t}^{k}\right)$ is the ex-post real return on capital, and $(1+\chi(\cdot))\left(1+i_{t-1}\right) \frac{P_{t-1}}{P_{t}}$ is the ex-post cost of borrowing. Net worth may then be expressed as a function of $V_{t}$ and the managerial wage, $W_{t}^{e} / P_{t}$,

\footnotetext{
${ }^{12}$ While we use the costly state verification problem to derive a parametric form for $\chi_{t}(\cdot)$, we note, however, that the general form relating external finance costs to financial positions arises across a broad class of agency problems.
} 


$$
N_{t+1}=\phi V_{t}+W_{t}^{e} / P_{t}
$$

where the weight $\phi$ reflects the number of entrepreneurs who survive each period. ${ }^{13}$

As equations (23) and (24) suggest, the principle source of movements in net worth stems from unanticipated movements in returns and borrowing costs. In this regard, unforecastable variations in the asset price $Q_{t}$ likely provide the principle source of fluctuations in $\left(1+r_{t}^{k}\right)$. It is for this reason that unpredictable asset price movements play a key role in the financial accelerator. On the liability side, unexpected movements in the price level affect ex post borrowing costs. An unexpected deflation, for example, reduces entrepreneurial net worth. If debt were instead denominated in foreign currency, then unexpected movements in the nominal exchange rate would similarly shift net worth - we explore this possibility later.

Entrepreneurs going out of business at time $t$ consume their remaining resources. Let $C_{t}^{e}$ denote the amount of the consumption composite consumed by the exiting entrepreneurs. ${ }^{14}$ Then

$$
C_{t}^{e}=(1-\phi) V_{t}
$$

is the total amount of equity that exiting entrepreneurs remove from the market.

\subsubsection{Capital Producers}

Competitive capital producers engage in two separate activities: the repair of depreciated capital and the construction of new capital goods. Both of these activities take place after production of output at time $t$. Following Eisner and Strotz [25] and Lucas [34], we assume that the construction of new capital goods is subject to adjustment costs whereas the repair of old capital goods is not. We further assume that there is no scope for substitution between repair of old capital and construction of new capital - that is, in order for old capital to be productive it must be repaired.

Both activities, repair and construction, use as input an investment good that is composed of domestic and foreign final goods:

$$
I_{t}=\left[\left(\gamma_{i}\right)^{\frac{1}{\rho_{i}}}\left(I_{t}^{H}\right)^{\frac{\rho_{i}-1}{\rho_{i}}}+\left(1-\gamma_{i}\right)^{\frac{1}{\rho_{i}}}\left(I_{t}^{F}\right)^{\frac{\rho_{i}-1}{\rho_{i}}}\right]^{\frac{\rho_{i}}{\rho_{i-1}}}
$$

\footnotetext{
${ }^{13}$ In our quantitative exercises, $W_{t}^{e}$ is of negligible size, and the dynamics of $N_{t}$ is determined by $V_{t}$.

${ }^{14}$ We assume that entrepreneurs have preferences over domestic and foreign goods that are identical to the households' preferences specified in equation (1). The optimal mix of foreign and domestic tradable goods for entrepreneurial consumption satisfies an equation analogous to (6).
} 
The production parameter $\gamma_{i}$ measures the relative weight that domestic and foreign inputs receive in the investment composite. Capital producers choose the optimal mix of foreign and domestic inputs according to the intra-temporal first-order-condition

$$
\frac{I_{t}^{H}}{I_{t}^{F}}=\frac{\gamma_{i}}{1-\gamma_{i}}\left(\frac{P_{t}^{H}}{P_{t}^{F}}\right)^{-\rho_{i}}
$$

with the investment price index, $P_{I, t}$, given by

$$
P_{I, t}=\left[\left(\gamma_{i}\right)\left(P_{t}^{H}\right)^{1-\rho_{i}}+\left(1-\gamma_{i}\right)\left(P_{t}^{F}\right)^{1-\rho_{i}}\right]^{\frac{1}{1-\rho_{i}}} .
$$

To repair depreciated capital, producers require $\delta\left(u_{t}\right) K_{t}$ units of the investment good which may be purchased at a cost of $\frac{P_{I, t}}{P_{t}} \delta_{t} K_{t}$. Consistent with equation (13), these costs are borne by the entrepreneurs who own the capital stock.

To construct new capital, producers use both investment goods and existing capital, which they lease from entrepreneurs. Let $I_{t}^{n}$ denote net investment - the amount of the investment good used for the construction of new capital goods

$$
I_{t}^{n}=I_{t}-\delta\left(u_{t}\right) K_{t}
$$

Each capital producer operates a constant returns to scale technology $\Phi\left(\frac{I_{t}^{n}}{K_{t}}\right) K_{t}$. Consistent with the notion of adjustment costs for net investment, $\Phi(\cdot)$ is increasing and concave. Under constant returns to scale, the resulting economy-wide capital accumulation equation is

$$
K_{t+1}=K_{t}+\Phi\left(\frac{I_{t}^{n}}{K_{t}}\right) K_{t}
$$

Individual capital producers choose inputs $I_{t}^{n}$ and $K_{t}$ to maximize expected profits from the construction of new investment goods. New capital goods are sold at a price $Q_{t}$. We assume, following BGG, that capital producers make their plans to produce new capital one period in advance. The idea is to capture the delayed response of investment observed in the data. The optimality condition for net investment satisfies

$$
E_{t-1}\left\{Q_{t} \Phi^{\prime}\left(\frac{I_{t}}{K_{t}}-\delta\left(u_{t}\right)\right)-\frac{P_{I, t}}{P_{t}}\right\}=0
$$

Equation (31) is a standard "Q-investment" relation, modified to allow for the investment delay $^{15}$. The variable price of capital, though, plays an additional role in this framework: as we have discussed, variations in asset prices will affect entrepreneurial balance sheets, and hence, the cost of capital.

\footnotetext{
${ }^{15}$ The second input into production, $K_{t}$, is required to preserve constant returns to scale. Let $r_{t}^{l}$ denote
} 


\subsubsection{Retailers, Price Setting, and Inflation}

We assume there is a continuum of monopolistically competitive retailers of measure unity. Retailers buy wholesale goods from entrepreneurs/producers in a competitive manner and then differentiate the product slightly (e.g., by painting it or adding a brand name) at a fixed resource cost $\kappa$. We assume that the fixed (from the retailers' point of view) resource cost represents distribution and selling costs that are assumed to be proportional to the steady-state value of wholesale output. We choose the level of the fixed costs so that profits to the retail sector are zero in steady-state. ${ }^{16}$

Let $Y_{t}^{H}(z)$ be the good sold by retailer $z$. Final domestic output is a CES composite of individual retail goods:

$$
Y_{t}^{H}=\left[\int_{0}^{1} Y_{t}^{H}(z)^{\frac{\vartheta-1}{\vartheta}} d z\right]^{\frac{\vartheta}{\vartheta-1}}-\kappa .
$$

The corresponding price of the composite final domestic good, $P_{t}^{H}$, is given by

$$
P_{t}^{H}=\left[\int_{0}^{1} P_{t}^{H}(z)^{1-\vartheta} d z\right]^{\frac{1}{1-\vartheta}} .
$$

Domestic households, capital producers, the government, and the foreign country buy final goods from retailers. Cost minimization implies that each retailer faces an isoelastic demand for his product given by $Y_{t}^{H}(z)=\left(\frac{P_{t}^{H}(z)}{P_{t}^{H}}\right)^{-\vartheta} Y_{t}^{H}$. Since retailers simply repackage wholesale goods, the marginal cost to the retailers of producing a unit of output is simply the relative wholesale price, $\frac{P_{W, t}}{P_{t}^{H}}$.

As we have noted, the retail sector provides the source of nominal stickiness in the economy. We assume retailers set nominal prices on a staggered basis, following the approach in Calvo [12]: each retailer resets his price with probability $(1-\theta)$, independently of the time elapsed since the last adjustment. Thus, each period a measure $(1-\theta)$ of producers reset

the lease rate for existing capital; then profits equal $Q_{t} \Phi\left(\frac{I_{t}^{n}}{K_{t}}\right) K_{t}-\frac{P_{I, t}}{P_{t}} I_{t}^{n}-r_{t}^{l} K_{t}$. The optimality condition for the choice of $K_{t}$ determines the equilibrium lease rate $r_{t}^{l}$ :

$$
E_{t-1}\left\{Q_{t}\left(\Phi\left(\frac{I_{t}^{n}}{K_{t}}\right)-\Phi^{\prime}\left(\frac{I_{t}^{n}}{K_{t}}\right) \frac{I_{t}^{n}}{K_{t}}\right)\right\}=r_{t}^{l}
$$

At the steady-state, there are no adjustments costs so that $\Phi(0)=\Phi^{\prime}(0)=0$. As a result, lease payments $r_{t}^{l} K_{t}$ are second-order and are negligible in terms of both steady-state and model dynamics.

${ }^{16}$ In addition to justifying zero profits for the retail sector, the presence of fixed costs in the production chain increases the economy-wide benefit to varying capital utilization at the margin. 
their prices, while a fraction $\theta$ keeps their prices unchanged. Accordingly, the expected time a price remains fixed is $\frac{1}{1-\theta}$. Thus, for example, if $\theta=.75$ per quarter, prices are fixed on average for a year.

Since there are no firm-specific state variables, all retailers setting price at $t$ will choose the same optimal value, $\bar{P}_{t}^{H}$. It can be shown that, in the neighborhood of the steady state, the domestic price index evolves according to

$$
P_{t}^{H}=\left(P_{t-1}^{H}\right)^{\theta}\left(\bar{P}_{t}^{H}\right)^{1-\theta} .
$$

Retailers free to reset choose prices to maximize expected discounted profits, subject to the constraint on the frequency of price adjustments. ${ }^{17}$ Here we simply observe that, within a local neighborhood of the steady state, the optimal price is

$$
\bar{P}_{t}^{H}=\mu \prod_{i=0}^{\infty}\left(P_{W, t+i}\right)^{(1-\beta \theta)(\beta \theta)^{i}}
$$

where $\mu=\frac{1}{1-1 / \vartheta}$ is the retailers' desired gross mark-up over wholesale prices. Note that if retail prices were perfectly flexible, equation (35) would simply imply $\bar{P}_{t}^{H}=\mu P_{W, t}$, i.e., the retail price would simply be a proportional mark-up over the wholesale price. However, because their prices may be fixed for some time, retailers set prices based on the expected future path of marginal cost, and not simply on current marginal cost.

Combining equations (34) and (35) yields an expression for the gross domestic inflation rate (within the neighborhood of a zero-inflation steady state):

$$
\frac{P_{t}^{H}}{P_{t-1}^{H}}=\left(\mu \frac{P_{W, t}}{P_{t}^{H}}\right)^{\lambda} E_{t}\left\{\frac{P_{t+1}^{H}}{P_{t}^{H}}\right\}^{\beta}
$$

where the parameter $\lambda=\frac{(1-\theta)(1-\beta \theta)}{\theta}$ is decreasing in $\theta$, the measure of price rigidity. Equation (36) is the canonical form of the new optimization-based Phillips curve that arises from an environment of time-dependent staggered price setting (see, e.g., Gali and Gertler [27]). The curve relates inflation to movements in real marginal cost and expected inflation.

Owing to imperfect competition, foreign goods sold in the local economy are subject to an analogous mark-up over the wholesale price. We assume that retailers of foreign goods face the marginal cost $P_{W, t}^{F}$ - see equation (11) - and set prices according to a Calvo-style

\footnotetext{
${ }^{17}$ Since it is standard in the literature, we do not report the maximization problem here.
} 
price setting equation. Let $1-\theta^{f}$ denote the probability that a retailer of foreign goods resets its price in any given period. The inflation rate for foreign goods then satisfies

$$
\frac{P_{t}^{F}}{P_{t-1}^{F}}=\left(\mu^{f} \frac{S_{t} P_{t}^{F *}}{P_{t}^{F}}\right)^{\lambda_{f}} E_{t}\left\{\frac{P_{t+1}^{F}}{P_{t}^{F}}\right\}^{\beta}
$$

where $\lambda_{f}=\frac{\left(1-\theta^{f}\right)\left(1-\beta \theta^{f}\right)}{\theta^{f}}$.. This specification of the pricing process for domestically-sold foreign goods implies temporary deviations from the law of one price owing to delay in the exchange rate pass-through mechanism. ${ }^{18}$ The coefficient $\theta^{f}$ captures the degree of this delay. When calibrating the model, we assume that retailers of domestic and foreign goods face the same degree of price rigidity, so that $\theta^{f}=\theta{ }^{19}$

CPI inflation is a composite of domestic and foreign good price inflation. Within a local region of the steady state, CPI inflation may be expressed as

$$
\frac{P_{t}}{P_{t-1}}=\left(\frac{P_{t}^{H}}{P_{t-1}^{H}}\right)^{\gamma}\left(\frac{P_{t}^{F}}{P_{t-1}^{F}}\right)^{1-\gamma} .
$$

\subsection{Resource Constraints}

The resource constraint for the domestic tradable good sector is

$$
Y_{t}^{H}=C_{t}^{H}+C_{t}^{e H}+C_{t}^{H *}+I_{t}^{H}+G_{t}^{H}
$$

where $G_{t}^{H}$ is government consumption and $C_{t}^{e H}$ is entrepreneurial consumption of the domestic good.

\subsection{Government Budget Constraint}

We assume that government expenditures are financed by lump-sum taxes and money creation as follows:

$$
\frac{P_{t}^{H}}{P_{t}} G_{t}^{H}=\frac{M_{t}-M_{t-1}}{P_{t}}+T_{t} .
$$

Government expenditures are exogenous. Lump sum taxes adjust to satisfy the government budget constraint. Finally, the money stock depends on monetary policy, which we will specify in the next section.

\footnotetext{
${ }^{18}$ Chari, Kehoe and McGrattan [15] also consider pricing-to-market specifications to explore the role of nominal rigidities in explaining exchange rate dynamics.

${ }^{19}$ Since foreign prices are exogenous, we can assume, without loss of generality, that the steady-state $\operatorname{markup} \mu^{f}=\mu$.
} 
Except for the description of monetary policy, we have completed the specification of the model. The distinctive aspect is the financial accelerator, characterized by just two equations: (22) and (24). The former characterizes how net worth influences capital demand. The latter describes the evolution of net worth. If we restrict the external finance premium $\chi(\cdot)$ to zero in equation (22), we effectively shut off the financial accelerator, and the model reverts to a reasonably conventional new open economy macroeconomic framework. In what follows, we will explore the performance of the model under alternative exchange rate regimes, with and without an operative financial accelerator.

\subsection{Fixed versus Flexible Exchange Rate Regimes}

In the quantitative analysis discussed in the next section, we consider shocks to the economy under three different scenarios: (i) a pure fixed exchange rate regime; (ii) a floating exchange rate regime, where the central bank manages the nominal interest rate according to a Taylor rule; and (iii) a hybrid case, where the central bank initially fixes the exchange rate, but then eventually abandons the peg in favor of the floating exchange rate regime. The latter regime is meant to approximate the monetary policy response over the crisis episode in Korea.

Under the fixed exchange rate regime, the central bank keeps the nominal exchange rate pegged at a predetermined level, i.e.

$$
S_{t}=\bar{S}, \forall t
$$

In doing so, the central bank sets the nominal interest rate to satisfy the uncovered interest parity condition given by equation (10).

Under the flexible exchange rate regime, the policy instrument becomes the nominal interest rate. The central bank adopts a feedback rule that has the nominal interest rate adjust to deviations of CPI inflation and domestic output from their respective target values. Let $Y_{t}^{0}$ denote the output target level, which we take to be the level that would arise if prices were perfectly flexible. The feedback rule, accordingly, is given by

$$
\left(1+i_{t}\right)=\left(1+r r^{s s}\right)\left(\frac{P_{t}}{P_{t-1}}\right)^{\gamma_{\pi}}\left(\frac{Y_{t}^{H}}{Y_{t}^{0}}\right)^{\gamma_{y}}
$$

with $\gamma_{\pi}>1$ and $\gamma_{y}>0$, and where $r r^{s s}$ is the steady state real interest rate. For simplicity, we take the target gross inflation rate to be unity. ${ }^{20}$ We interpret this rule as being a form

\footnotetext{
${ }^{20}$ The results are robust to allowing for a managed float, where the Tayor rule is appended with a term that allows for a modest adjustment of the nominal interest rate to deviations of the nominal exchange rate from target.
} 
of flexible inflation targeting, in the sense of Bernanke et al. [8]. The central bank adjusts the interest rate to ensure that over time the economy meets the inflation target, but with flexibility in the short term so as to meet stabilization objectives. Importantly, we assume that the central bank is able to credibly commit to the Taylor rule.

In the hybrid regime, as a shock hits the economy, the central bank initially maintains the exchange rate peg. Conditional on being on the peg in the current period, it abandons the peg with probability $\Pi$ in the subsequent period, where $\Pi$ is independent of time. Once off the peg, the central bank reverts to the interest rate feedback rule given by equation (42).

\subsection{Model Parametrization}

Our quantitative analysis is meant to capture the broad features of an emerging market economy such as South Korea for which financial frictions seem particularly relevant. We first discuss the choice of the parameters governing preferences and technology, and then describe the choice of the parameters pertinent to the financial structure.

\subsubsection{Preferences}

We fix the quarterly discount factor $\beta$ at 0.99 . We set the elasticity of inter-temporal substitution, $\frac{1}{\sigma}$, equal to 0.2 , consistent with the evidence of low sensitivity of expected consumption growth to real interest rates. Since consumption goods are thought to have a higher degree of substitution than intermediate or investment goods, ${ }^{21}$ we set the intratemporal elasticity of substitution for the consumption composite, $\rho_{h}$, at unity and the intratemporal elasticity of substitution for the investment composite, $\rho_{i}$, at 0.25 . To match the average ratio of consumption to GDP in Korea over the period 1990-2002 - approximately 0.5 - we set the share of domestic goods in the consumption composite, $\gamma$, equal to 0.5 . Finally, we assume that the elasticity of labor supply is equal to 2 and that average hours worked relative to total hours available are equal to $\frac{1}{3}$.

With regard to the parameters of the export demand, equation (12), we set the elasticity $\varkappa$ equal to 1 and the share parameter, $\nu$, equal to 0.25 . This implies a relatively high degree of inertia in export demand, in line with the response of Korean exports during the 1997-98 crisis.

\footnotetext{
${ }^{21}$ Around fifty percent of Korean imports are intermediate goods.
} 


\subsubsection{Technology}

Over the period 1990-2002, the average gross capital formation-to-GDP and exports-to-GDP ratios in Korea were approximately 0.3 and 0.4 , respectively. To match these characteristics, we set the capital share, $\alpha$, equal to 0.5 , the share of domestic goods in the investment composite, $\gamma_{i}$, equal to 0.5 , and the steady state ratio of exports to domestic output equal to 0.4 . We set $\Omega=0.01$, implying that entrepreneurial labor accounts for $1 \%$ of the total wage bill. The steady state utilization rate is normalized at 1 and the steady state quarterly depreciation, $\delta\left(u_{s s}\right)$, is assigned the conventional value of 0.025 , consistent with the evidence. The parameter $\xi$, which represents the elasticity of marginal depreciation with respect to the utilization rate, $\frac{u \delta^{\prime \prime}(u)}{\delta^{\prime}(u)}$, is set equal to 1, consistent with Baxter and Farr [5], who rely on estimates provided by Basu and Kimball [3]. The steady state mark-up value, $\mu$, is set at 1.2. Consistent with the retail sector earning zero profits in steady state, the fixed resource $\operatorname{cost} \kappa$ is assumed to be 20 percent of wholesale output. The elasticity of the price of capital with respect to the investment-capital ratio is taken to be 2 . As is common in the literature on the Calvo [12] pricing technology, we assume the probability of the price not adjusting, $\theta$, to be 0.75 .

\subsubsection{External Finance Premium}

The data suggest that capital markets in Korea are somewhat less developed relative to the U.S.. Debt-equity ratios were particularly high at the onset of the financial crisis. ${ }^{22}$ Early in 1998, the Korean authorities urged the thirty largest chaebols to reduce their debt-equity ratios to "below 2" by the end of 1999 . Conservatively, we set the steady state leverage ratio equal to 1.1, approximately twice the historical U.S. average.

The spread between corporate and government bond rates appears to be consistently zero prior to 1997 (see Figure 2). We interpret this as evidence of some sort of explicit/implicit government guarantees to the Korean corporate sector. After reaching nine percent in December 1997-January 1998, the spread dropped and stabilized at around 1-2 percent in the late spring of 1998. Since there is still some evidence of government meddling in capital markets in Korea, we set the steady state external finance premium at 3.5 percent, roughly 150 basis points higher than U.S. historical data.

\footnotetext{
${ }^{22}$ According to Krueger and Yoo [33], in 1997 the debt-equity ratio was 5.2 for the thirty largest chaebols, 4.8 for the five largest chaebols, 4.6 for the five largest manufacturing firms, and 3.9 for all firms in the manufacturing sector
} 
To obtain these steady state values, we need to set the non-standard parameters of the model that affect the relation between real and financial variables. In particular, we set the entrepreneurs' death rate, $(1-\phi)$, equal to 0.0272 . We assume that the idiosyncratic productivity variable $\omega_{t}$ is log-normally distributed with variance equal to 0.28 . Finally, we fix the fraction of realized payoffs lost in bankruptcy, $\mu_{b}$, to 0.12 .

\subsubsection{Government Policy}

We set the Taylor rule coefficients on CPI inflation and domestic output gap, $\gamma_{\pi}$ and $\gamma_{y}$ respectively, equal to 2 and 0.75 , respectively. These coefficients provide a reasonable approximation of the response of the real interest rate in Korea after the abandonment of the fixed exchange rate regime. Finally, we take the steady state government expenditure ratio, $\frac{G^{H}}{Y^{H}}$, to be 0.2 .

\section{External Shocks and Financial Crises: a Quantitative Assessment}

In this section we evaluate how well the model is able to replicate a financial crisis, such as the one that occurred in Korea. In particular, we consider the response of the model economy to an exogenous rise in the country risk premium, meant to reflect the sudden and unanticipated capital outflows that appear to have triggered the events that followed the Korean crisis, as we discussed in section 2. We begin with some simple exercises meant to illustrate the model dynamics and the sensitivity of these dynamics to the exchange rate regime. We then turn to an experiment meant to replicate the Korean crisis episode. Finally, for Korea, only about twenty-five percent of debt was in units of foreign currency. ${ }^{23}$ For this reason, in our baseline exercises we assumed that debt was in domestic currency units. We conclude this section, however, by considering the implications of having debt denominated entirely in units of foreign currency.

\footnotetext{
${ }^{23}$ This refers to the share of liabilities denominated in foreign currency for commercial banks in Korea in January/February 1998. See Krueger et al. [33] for details.
} 


\subsection{Country Borrowing Premium Shock}

To illustrate the workings of the model, we consider an unanticipated one hundred basis point increase in the country borrowing premium, $\Psi_{t} \cdot{ }^{24}$ We assume further that the shock obeys a first-order auto-correlation process that persists at the rate of 0.95 per quarter. Figures $4 \mathrm{~A}$ and $4 \mathrm{~B}$ plot the response of twelve key variables under fixed versus floating rates.

Under the fixed exchange rate regime, the domestic nominal interest rate rises to match the increase in the country borrowing premium. Due to nominal price rigidities, there is also a significant increase in the real interest rate which, in turn, induces a contraction in output. The financial accelerator magnifies the output drop - the rise in the real interest rate induces a contraction in asset prices, which raises the leverage ratio and the external finance premium. The increase in the latter further dampens investment and output.

Under a flexible exchange rate, the domestic nominal interest rate is no longer tied to the foreign interest rate, and is instead governed by the feedback rule, equation (42). The rise in the country risk premium produces an immediate depreciation of the domestic currency, which in turn prompts an increase in exports and a sharp rise in CPI inflation. The central bank raises the nominal interest rate to fight inflation, according to the feedback rule. This monetary policy implies only a modest increase in the real interest rate however, and a moderate drop in investment. Because the rise in domestic inflation is due to the currency depreciation, it is short-lived. Nominal rates fall back to trend one period after the shock while real rates fall slightly below trend. Output falls slightly on net, due to offsetting effects of a reduction in investment demand and increasing exports. Overall, output is significantly more stable under the flexible exchange rate regime. ${ }^{25}$

Figure $4 \mathrm{~A}$ also shows the effect of the contraction in output on capital utilization and labor productivity. With either fixed or flexible exchange rates, the reduction in output implies a reduction in capital utilization of almost equal magnitude. As a consequence, labor productivity falls following a demand-driven slow-down, despite the fact that hours

\footnotetext{
${ }^{24}$ Note that, in this framework, this shock is formally equivalent to a shock to the foreign interest rate. In addition, we have explored alternative experiments, such as shocks to foreign prices. These experiments yield very similar conclusions with regard to the effects of fixed versus flexible exchange rates in the presence of the financial accelerator.

${ }^{25}$ The monetary policy rule includes the output gap as well as inflation. In principal, output stability is influenced by the combined effect of targeting inflation and the output gap. Using an interest rate rule that puts zero weight on the output gap produces very similar results however. With zero weight on the output gap, the contraction in output produces less inflationary pressures and hence less need to raise real rates to fight inflation.
} 
are contracting. The model implies a strongly pro-cyclical movement in measured TFP under fixed rates, measured TFP drops one and one half percent in response to a two percent drop in utilization - despite the absence of any exogenous change in technology. Note that the drop in measured TFP and utilization relative to output is roughly in line with data from the Korean crisis period (where, again, utilization is measured by electricity usage.) These results suggest that the model is capable of producing quantitatively realistic dynamics of measured productivity, even though the underlying shock is financial in nature, and not technological.

The last two panels of Figure 4A show the effect of the rise in the country risk premium on consumption and net exports. With a flexible exchange rate, consumption falls more than output owing to the increased cost of imported consumer goods following the depreciation. With fixed rates, this effect is muted and consumption falls by slightly less than output. As expected, with flexible rates, net exports increase, albeit by a modest amount. Net exports also increase under fixed rates, due to the contraction in import demand, stemming from the sharp investment and output decline. Indeed, the rise in net exports is substantially larger

under fixed exchange rates, despite the fact that the real exchange rate depreciates more under the flexible exchange rate regime.

Overall, these results imply a much larger drop in output, hours (not shown), and investment under a fixed exchange rate regime than under a flexible exchange rate regime in response to a rise in the country risk premium. That output should decline more under fixed rates in this scenario is, of course, a feature of the standard model absent a financial accelerator. What we wish to stress here is that the financial accelerator greatly magnifies the difference. Figure 5 makes this point directly. The figure plots the response of output and investment across the two different exchange rate regimes, with and without an operative financial accelerator. Under fixed rates, the financial accelerator doubles the contraction in investment (lower left panel) and more than doubles the contraction in output (upper left panel) at the trough. Under flexible rates, instead, the effect of the financial accelerator is far more modest.

\subsection{The Korean Experience}

We now turn to a quantitative exercise that is intended to capture the macroeconomic consequences of the rise in the country risk premium that occurred in Korea during its recent financial crisis. Our goal is to analyze the quantitative response of our model under 
such a scenario and compare the model outcome with the actual Korean data. Within the context of our model, an exogenous rise in the country borrowing premium introduces a wedge between domestic and foreign interest rates in the uncovered interest parity condition (see equation 10). Formally, it is equivalent to a shock to the foreign interest rate. As discussed above, we believe that treating the rise in the country risk premium as exogenous is a reasonable approximation of the Korean situation. ${ }^{26}$

We consider a five percentage point rise in the country risk premium, which is in line with the rise in the EMBI Global that occurred in Korea during the financial crisis. We assume that the shock persists as a first-order autoregressive process with a 0.95 coefficient, which is also in line with the evidence. ${ }^{27}$ We capture the notion that Korea began the episode under a fixed exchange rate regime and then subsequently abandoned the peg as follows: we assume that the exchange rate is initially fixed when the shock hits, but that the central bank may either bandon the regime in any subsequent period with a fixed probability $\Pi$ or continue the peg with fixed probability $1-\Pi$. Because the Korean devaluation was largely unanticipated, we set the abandonment probability at a relatively low value, 0.1. Accordingly, conditional on being on the peg, the expected duration is $\frac{1}{\Pi}=\frac{1}{0.1}=10$ quarters. To roughly match the Korean experience, we set the actual abandonment at two quarters after the shock ${ }^{28}$ (thus, the abandonment occurs sooner than the market would have guessed ex-ante). For benchmark purposes, we also report how the economy would have responded under a pure fixed exchange rate regime and a pure flexible exchange rate regime.

Figure $6 \mathrm{~A}$ and $6 \mathrm{~B}$ plot the response of twelve key variables under the policy of probabilistic abandonment, along with the response under fixed and flexible exchange rates. Overall, the model with probabilistic abandonment does well at capturing the key outcomes of the Korean experience displayed in Figures 1-3 above. In the Korean data, the drop in real GDP

\footnotetext{
${ }^{26}$ Cooper and Ejarque [22] provide a model with an endogenous collapse of the banking sector applied to the Great Depression. Their model, however, does not provide an endogenous amplification of the collapse through a financial accelerator mechanism.

${ }^{27}$ Even after controlling for the sharp spike in the EMBI Global following the Russian crisis in 1998, it appears that the increase in the Korean spread was persistently high after the 1997 Asian crisis.

${ }^{28}$ The reason why we set two quarters before the regime switch in our Korean experiment is the following. Even though the IMF stand-by credit for Korea, approved on December 4, 1997, included a flexible exchange rate policy, monetary policy was tightened to restore and sustain calm in the markets, and to contain the inflationary impact of the won depreciation. This implied a reversal of liquidity injected prior to the IMF program and a sharp increase in money market rates - see Figure 2 - to stabilize the markets. Since rates were reduced only gradually in 1998, we don't characterize the end-1997/beginning-1998 period as a switch to flexible inflation targeting yet.
} 
is fourteen percent whereas the model produces roughly a thirteen percent drop. ${ }^{29}$ The reduction in gross capital formation for Korea is on the order of forty-five percent, again in line with, albeit somewhat larger than, the model's thirty-five percent response. Net exports (as a percentage of GDP) increase by fifteen percent in the data, compared with nearly fourteen percent in the model. Notably, both the data and the model imply a large reduction in imports, especially capital goods, which drives the expansion in net exports. In the data, consumption falls by roughly eighteen percent, which is about double the nine percent implied by the model. A good chunk of this discrepancy, though, might be explained by the fact that data includes durables as well as non-durables, while consumption in the model includes only non-durables.

The model also does well at capturing the productivity and utilization variables observed in Korea over this time period. The Korean data imply a five percent drop in labor productivity over the period December 1997 through September 1998 while the model implies roughly a three percent drop. The magnitude of the decline in labor productivity observed in the data is probably exagerated, however, since it is based on output per worker and not on output per hour. ${ }^{30}$ As shown in figure 1, electricity consumption for the Korean economy falls fourteen percent during the crisis period. In the model, capital utilization drops eleven percent, in the same ballpark as the decline in electricity utilization. ${ }^{31}$ Overall, these results imply that variable capital utilization provides a reasonable explanation for the contraction in productivity that emerging market economies such as Korea experience in the wake of a financial crisis.

Finally, the model also does well at capturing various financial features of the Korean experience. The nine percentage point rise in the corporate-treasury bond spread observed in the data is very close in magnitude to the response obtained by the model's external finance premium. In addition, the model does a good job of capturing the sudden reduction

\footnotetext{
${ }^{29}$ Because agents expect the monetary authority to abandon eventually, expected future inflation is higher and, consequently, so is current inflation. As a result, both nominal and real interest rates rise by more under the model with probabilistic abandonment than in the case of a pure fixed exchange rate.

${ }^{30} \mathrm{~A}$ stylized fact for U.S. data is that, of the total drop in hours during a typical recession, roughly one third reflects a drop in hours per worker. Not taking into account the hours per worker change, accordingly, suggests a significant exageration of the movement in labor productivity (based on measures that use employment as opposed to hours).

${ }^{31}$ Given that oil is an imported good, we would expect some substitution away from energy towards other capital goods and inputs in the case where energy and capital show some degree of substitutability. Hence the fourteen percent drop in energy is likely to overstate the decline in capital services owing to a drop in utilization rates.
} 
in the corporate-treasury bond spread following the abandonment of the peg. It also does well at mimicing both the nominal and real interest rate movements observed in the data. In particular, in the data, the (ex-post) real interest rate initially rises by eight percentage points prior to the abandonment, and then falls by sixteen percentage points following the abandonment - a result that is similar to the real rate path generated by the model. ${ }^{32}$ Consistent with this path, both the data and the model exhibit a surge in inflation - on the order of five percentage points - following the abandonment.

The financial variable that is difficult to match is the actual exchange rate movement when the monetary authority abandons the fixed exchange rate regime probabilistically. The fact that quantitative macroeconomic models have difficulty in matching exchange rate movements comes as no surprise however. Our model nonetheless produces a sizable depreciation in the real exchange rate - on the order of ten percent. As it is well known, movements in the nominal exchange rate dramatically over-state movements in the real exchange rate and the terms of trade. ${ }^{33}$ To the extent that our model does well at capturing the dynamic response of net exports, we are less concerned that it does not fully account for the volatility of the exchange rate during this time period.

Up to the point where the peg is abandoned, the contraction is as severe as if the economy had been on a lasting peg. The abandonment, of course, frees the hand of monetary policy and allows the economy to recover much faster than otherwise. As the figures indicate, the crisis would have been much less severe had the economy all along been operating in a credible floating exchange rate regime.

We now consider the welfare loss associated with the financial crisis, as well as the loss that might have occurred under alternative policy scenarios. In particular, we compute the drop in household and entrepreneurial utility suffered during the crisis and then convert this drop into consumption-equivalents. In doing so, we measure the crisis period to be six

\footnotetext{
${ }^{32}$ Although we don't have data on ex-ante real interest rates, it is useful to look at the ex-post real interest rate as a guide. The nominal interest rate rises from thirteen to twenty-five percent on an annual basis in January 1998, before falling to five percent by September 1998. The inflation rate rises from five percent in the third quarter of 1997 to nine percent in the first quarter of 1998 before falling to six percent by September of 1998. Thus, the ex-post real rate is approximately eight percent in October 1998, sixteen percent in January 1998 and zero percent in September 1998, indicating an initial eight percentage point rise followed by a sixteen percentage point fall in the real interest rate.

${ }^{33}$ As emphasized by Burstein, Eichenbaum and Rebelo [9], in the absence of a substantial non-tradable good sector, it is extremely difficult to match movements in the nominal exchange rate. Barth and Dinmore [4] provide further discussion of the response of the real exchange rate and the terms of trade for various Asian countries during the financial crisis.
} 


\section{Table 1: Welfare Loss As a Percent of Steady-State Consumption Model with Financial Accelerator \\ Flexible Rates $\quad 12.1 \%$ \\ Switching Regime $\quad 16.4 \%$ \\ Fixed Rates $\quad 20.5 \%$}

quarters, approximately the amount of time it took for Korea's detrended GDP to recover to its pre-crisis level. We then calculate the amount of steady state consumption that an appropriately weighted average of households and entrepreneurs would be willing to forgo as a one-time payment to avoid the present-discounted loss in utility associated with the crisis. ${ }^{34}$ We express the amount that individuals are willing to forgo as a fraction of one year's steady state consumption. Details of the calculations are in an accompanying appendix. These results are reported in table 1. In the case meant to capture the Korean crisis, the "Switching Regime," the welfare loss of the crisis is quite substantial, sixteen percent of one year's consumption. Had the economy stayed on fixed rates throughout, the loss would have been considerable worse, twenty percent of steady state annual consumption. Had the economy been on flexible rates, the welfare loss would have still been considerable - twelve percent of one year's consumption - but, nonetheless, significantly lower than under the other policy regimes, especially the pure fixed exchange rate regime.

\subsection{Foreign-denominated Debt}

A number of authors have recently stressed that if private debts are denominated in foreign currency units - as was recently the case for many emerging market economies - a fixed exchange rate regime may in fact be more desirable than a flexible exchange rate regime, since devaluations weaken borrower balance sheets. ${ }^{35}$ As we have discussed, in the Korean case, only about a quarter of all debts were denominated in foreign currency, which led us to consider debt in domestic currency as the baseline case. Nonetheless, it is useful to explore the extent to which our conclusions are robust to having foreign-indexed debt. Accordingly, we briefly consider the effect of foreign-indexed debt for the response of the model to an

\footnotetext{
${ }^{34}$ The loss incorporates the current and future foregone consumption of households and entrepreneurs as well as the gain in current and future household leisure that accompanies the crisis.

${ }^{35}$ See, for example, Aghion, Bacchetta and Banerjee [2].
} 
unanticipated one hundred basis point increase in the country borrowing premium. ${ }^{36}$

Figure 6 plots the response of output and investment under three different scenarios: flexible exchange rate with debt denominated entirely in foreign currency; flexible exchange rate with domestic-denominated debt; and fixed exchange rate. As one would expect, foreign currency debt makes the flexible exchange rate regime considerably less attractive. Allowing for foreign currency debt implies a contraction in investment that is twice as large as the contraction obtained in the case of domestic currency debt. With foreign currency debt, the depreciation of the exchange rate reduces entrepreneurial net worth, thus enhancing the financial accelerator mechanism. Nonetheless, even in this instance, the output drop remains smaller under flexible rates than under fixed rates. Put differently, the impact of the exchange rate on the balance sheets under flexible rates is less damaging than the contraction in asset prices under fixed rates. Our conclusion that a flexible rate regime remains dominant, even with foreign-indexed debt, is consistent with the conclusions of Cespedes, Chang and Velasco [14], though the details of the transmission mechanisms under fixed versus flexible rates differ significantly.

\section{Concluding Remarks}

We developed a small open economy general equilibrium framework that featured money, nominal price rigidities, and a financial accelerator mechanism. The goal was to explore the interaction between the exchange rate regime and financial crises. As a way to judge the framework, we explored how well it was able to explain the behavior of the Korean economy over the 1997-98 period of financial crisis. We found that overall the model does well. It is able to match the observed drop in Korean output, investment, and productivity during this time period. The financial accelerator mechanism turns out be quantitatively significant accounting for about 50 percent of the total reduction in output. In addition, the model can

\footnotetext{
${ }^{36}$ In the presence of debt denominated in foreign currency, the entrepreneurial net wealth and the external finance premium equations are modified as follows:

$$
V_{t}=\left(1+r_{t}^{k}\right) Q_{t-1} K_{t}-\left[(1+\chi(\cdot))\left(1+i_{t-1}^{*}\right) \frac{S_{t}}{S_{t-1}} \frac{P_{t-1}}{P_{t}}\right] \frac{B_{t}^{*}}{P_{t-1}}
$$
}

and

$$
E_{t}\left\{1+r_{t+1}^{k}\right\}=\left(1+\chi_{t}(.)\right) E_{t}\left\{\left(1+i_{t}^{*}\right) \frac{S_{t+1}}{S_{t}} \frac{P_{t}}{P_{t+1}}\right\}
$$


account for most of the large drop in measured labor productivity by appealing to variable capital utilization.

Our counterfactual exercises suggested that a policy of fixed exchange rates can lead to substantially higher welfare losses following a financial crisis than would have been obtained under a policy of flexible inflation targeting. The flexible inflation targeting policy was characterized by floating exchange rates and a well formulated Taylor rule that had the nominal interest rate adjust to stabilize inflation and the output gap. Of course, our counterfactual experiment assumed that the Taylor rule was fully credible. In practice, however, successful implementation of a "good" Taylor rule requires that the overall economic infrastructure must be sound, e.g., the domestic budget cannot be out of control. This kind of considerations, however, poses a dilemma for the successful working of any kind of monetary regime. Indeed, as Obstfeld and Rogoff [36] note, given that fixed exchange rate regimes never seem to last, it is not clear that this kind of policy can solve the credibility problem. Nonetheless, we concede that a better understanding of how credibility considerations factor into the choice of exchange regimes is an important topic for future research. 


\section{References}

[1] ANDERSON, G. and G. MOORE (1985), "A Linear Procedure for Solving Linear Perfect Foresight Models", Economics Letters, 17, 247-252.

[2] AGhion, P., BACChetta, P. and BAnERJEe, A. (2000), "A Simple Model of Monetary Policy and Currency Crises", European Economic Review, 44, 728-738.

[3] BASU, S. and KIMBALL M. (1997), "Cyclical Productivity and Unobserved Input Variation" (NBER Working Paper No. 5915).

[4] BARTH, M.J. and DINMORE T. (1999), "Trade Prices and Volumes in East Asia Through the Crisis" (Board of Governors of the Federal Reserve System IFDP Paper No. 643$)$.

[5] BAXTER, M. and FARR D. (2001), "Variable Factor Utilization and International Business Cycle" (NBER Working Paper No. 8392).

[6] BERNANKE, B. and GERTLER M. (1989), "Agency Costs, Net Worth, and Business Fluctuations", American Economic Review, 79, 14-31.

[7] BERNANKE, B., GERTLER M. and GILCHRIST S. (2000), "The Financial Accelerator in a Quantitative Business Cycle Framework", Handbook of Macroeconomics (North Holland).

[8] BERNANKE, B., LAUBACH, T., MiSHKIN, F., and Posen, A. (1999) Inflation Targeting. Lessons from the International Experience (Princeton University Press).

[9] BURSTEIN, A., EICHENBAUM, M. and REBELO, S. (2002), "Why are Rates of Inflation so Low After Large Devaluations?" (NBER Working Paper No. 8748).

[10] BURNSIDE, C., EICHENBAUM, M., and REBELO, S. (2001), "Hedging and Financial Fragility in Fixed Exchange Rate Regimes", European Economic Review, 45, 1151-1193.

[11] CABAlLERO, R.J. and KRISHNAMURTHY, A. (2000), "Emerging Markets Crises: an Asset Markets Perspective" (MIT, mimeo).

[12] CALVO, G. (1983), "Staggered Prices in a Utility-Maximizing Framework", Journal of Monetary Economics, 12, 383-398. 
[13] CARLSTROM, C. and FUERST, T. S. (1997), "Agency Costs, Net Worth, and Business Fluctuations: a Computable General Equilibrium Analysis", American Economic Review, 87, 893-910.

[14] CESPEDES, L.P., CHANG, R. and VELASCO, A. (2000), "Balance Sheets and Exchange Rate Policy" (NBER Working Paper No. 7840).

[15] CHARI, V.V., KEHOE, P.J., and MCGRATTAN, E. (2002), "Can Sticky Price Models Generate Volatile and Persistent Real Exchange Rates?" (Federal Reserve Bank of Minneapolis, Staff Report No. 277).

[16] CHARI, V.V., KEHOE, P.J., and MCGRATTAN, E. (2003), "Accounting for the Great Depression", Quarterly Review, Vol. 27 No. 2, Federal Reserve Bank of Minneapolis.

[17] CHRISTIANO, L., GUST, C., and ROLDOS, J. (2002), "Monetary Policy in a Financial Crisis" (NBER Working Paper No. 9005).

[18] CLARIDA, R., GALI, J. and GERTLER, M. (1998), "Monetary Policy Rules in Practice: Some International Evidence", European Economic Review, 42, 1033-1067.

[19] CLARIDA, R., GALI, J. and GERTLER, M. (1999), "The Science of Monetary Policy: a New Keynesian Perspective", Journal of Economic Literature, 37, 1661-1707.

[20] COLE, H. and OHANIAN, L. (2001), "Re-Examining the Contributions of Money and Banking Shocks to the U.S. Great Depression" in Ben Bernanke and Kenneth Rogoff (eds.),. NBER Macroeconomics Annual (MIT Press).

[21] COLE, H. and OHANIAN, L. (2002), "Did Monetary Forces Cause the International Great Depression" (Federal Reserve Bank of Minneapolis).

[22] COOPER, R. and EJARQUE, J. (1995), "Financial Intermediation and the Great Depression: A Multiple Equilibrium Interpretation", Carnegie-Rochester Series on Public Policy, 43, 285-323.

[23] DEVEREUX, M. and LANE, P. (2003), "Exchange Rates and Monetary Policy in Emerging Market Economies" (UBC ,mimeo).

[24] EICHENGREEN, B. (1992), The Gold Standard and the Great Depression, 1919-1939 (New York: Oxford University Press). 
[25] EISNER, R. and STROTZ, R. (1963), "Determinants of Business Investment", (with bibliography by G.R. Post) in Commission on Money and Credit Impacts of Monetary Policy, 59-337 (Englewood Cliffs: Prentice-Hall).

[26] FUERST, T. S. (1995), "Monetary and Financial Interactions in the Business Cycle", Journal of Money, Credit, and Banking, 27, 1321-1338.

[27] GALI, J. and GERTLER, M. (1999), "Inflation Dynamics: a Structural Analysis", Journal of Monetary Economics, 44, 195-222.

[28] GALI, J. and MONACELLI, T. (2002), "Monetary Policy and Exchange Rate Volatility in a Small Open Economy" (NBER Working Paper No. 8905).

[29] GREENWOOD, J., HERCOWITZ, Z. and HUFFMAN, G. (1988), "Investment, Capital Utilization, and the Real Business Cycle", American Economic Review, 78, 402-417.

[30] KAMINSKY, G.L and REINHART, C.M. (1999), "The Twin Crises: the Causes of Banking and Balance-of-Payments Problems", American Economic Review, 89, 473500.

[31] KIYOTAKI, N. and MOORE, J. (1997), "Credit Cycles", Journal of Political Economy, $105,211-248$.

[32] KRISHNAMURTHY, A. (2003), "Collateral Constraints and the Amplification Mechanism," Journal of Economic Theory, 277-292.

[33] KRUEGER, A. and YOO, J. (2001), "Chaebol Capitalism and the Currency-financial Crisis in Korea" (NBER Conference on Currency Crises Prevention).

[34] LUCAS, R.E. Jr. (1967), "Optimal Investment Policy and the Flexible Accelerator," International Economic Review, 8, 78-85.

[35] MONACELLI, T. (1999), "Into the Mussa Puzzle: Monetary Policy Regimes and the Real Exchange Rate in a Small Open Economy" (Boston College Working Paper in Economics No. 437).

[36] OBSTFELD, M. and ROGOFF, K. (1995), "The Mirage of Fixed Exchange Rates", Journal of Economic Perspectives, 9, 73-96. 
[37] OBSTFELD, M. and ROGOFF, K. (1999), "New Directions for Stochastic Open Economy Models" (NBER Working Paper No. 7313).

[38] REBELO, S. and VEGH, C. A. (1995), "Real Effects of Exchange Rate-Based Stabilization: an Analysis of Competing Theories" (NBER Working Paper No. 5197).

[39] SCHMiTT-GROHE, S. and URIBE, M. (2001), "Stabilization Policy and the Costs of Dollarization", Journal of Money, Credit, and Banking, 33, 482-509.

[40] SCHNEIDER, M. and TORNELL, A. (2000), "Balance Sheet Effects, Bailout Guarantees and Financial Crises" (NBER Working Paper No. 8060).

[41] SVENSSON, L.E.O. (2000), "Open-Economy Inflation Targeting", Journal of International Economics, 50, 155-183.

[42] TAYLOR, J. B. (1993), "Discretion Versus Policy Rules in Practice", CarnegieRochester Series on Public Policy, 39, 195-214.

[43] TOWNSEND, R. M. (1979), "Optimal Contracts and Competitive Markets with Costly State Verification', Journal of Economic Theory, 21, 265-293.

[44] URIBE, M. (1997), "Exchange-Rate-Based Inflation Stabilization: the Initial Real Effects of Credible Plans", Journal of Monetary Economics, 39, 197-221. 


\section{Appendix}

\section{Welfare calculations:}

Assuming real money balance effects are negligible, we can write the household's utility function at time $t$ as

$$
U_{t}^{h}=\frac{\left[\left(C_{t}\right)^{1-\varsigma}\left(1-L_{t}\right)^{\varsigma}\right]^{1-\sigma}}{1-\sigma} .
$$

Since the entrepreneur's utility function at time $t$ is given by

$$
U_{t}^{e}=C_{t}^{e}
$$

then in steady state we have

$$
U_{s s}^{h}=\frac{\left[\left(C_{s s}\right)^{1-\varsigma}\left(1-L_{s s}\right)^{\varsigma}\right]^{1-\sigma}}{1-\sigma}
$$

and

$$
U_{s s}^{e}=C_{s s}^{e}
$$

From equation (9), the household's marginal utility of consumption at time $t$ is given by

$$
\lambda_{t}^{h}=\frac{\partial U_{t}^{h}}{\partial C_{t}}=(1-\phi)\left(C_{t}\right)^{(\sigma-1)(\phi-1)-1}\left(1-L_{t}\right)^{\phi(1-\sigma)}
$$

while the entrepreneur's marginal utility of consumption is 1 .

Let the present discounted value of the household's and entrepreneur's utility along the time path be

$$
W_{t}^{h}=\sum_{t=1}^{k} \beta^{t-1} U_{t}^{h}
$$

and

$$
W_{t}^{e}=\sum_{t=1}^{k} \beta^{t-1} U_{t}^{e}
$$

Finally, let the utility of the household and the entrepreneur corresponding to a constant sequence of consumption and leisure be

$$
W_{s s}^{h}=\frac{U_{s s}^{h}\left(1-\beta^{k}\right)}{1-\beta}
$$

and

$$
W_{s s}^{e}=\frac{U_{s s}^{e}\left(1-\beta^{k}\right)}{1-\beta}
$$


Then the welfare cost of the business cycle is given by

$$
\frac{\Delta C_{s s}^{t o t}}{C_{s s}^{t o t}}=\left[(\tau) \frac{W_{t}^{h}-W_{s s}^{h}}{\lambda_{s s}^{h} C_{s s}}+(1-\tau) \frac{W_{t}^{e}-W_{s s}^{e}}{C_{s s}^{e}}\right]
$$

where $\tau$ is the household share of total steady state consumption:

$$
\tau=\frac{C_{s s}}{C_{s s}+C_{s s}^{e}}
$$

\section{The financial contract:}

In this section of the appendix, we describe the derivation of the optimal contract in the non-stochastic steady-state. We then show how to log-linearize the key financial equation, around this steady-state value. Given the solution to the contract, the rest of the model can be log-linearized in a standard fashion.

Let profits per unit of capital equal $\omega \bar{R}^{k}$ where $\ln (\omega) \sim N\left(-(1 / 2) \sigma^{2}, \sigma^{2}\right)$ so that $E(\omega)=$ $1 .{ }^{37}$ Let $N$ denote the steady-state level of net worth, $Q$ the price of capital (equal to one in steady-state) and $K$ the steady-state value of the capital stock. The entrepreneur borrows $Q K-N$ to invest $K$ units of capital in a project. The total return on capital is $\omega \bar{R}^{k} Q K$ where $\bar{R}^{k}$ denotes the steady-state return on capital. We assume $\omega$ is unknown to both the entrepreneur and the lender prior to the investment decision. After the investment decision is made, the lender can only observe $\omega$ by paying the monitoring cost $\mu^{b} \omega \bar{R}^{k} Q K$, where $0<\mu^{b}<1$. The required return on lending equals $R=1 / \beta$.

The optimal contract specifies a cutoff value $\bar{\omega}$ such that if $\omega \geq \bar{\omega}$, the borrower pays the lender the fixed amount $\bar{\omega} \bar{R}^{k} Q K$ and keeps the equity $(\omega-\bar{\omega}) \bar{R}^{k} Q K$. Alternatively, if $\omega<\bar{\omega}$, the borrower receives nothing, while the lender monitors the borrower and receives $\left(1-\mu_{b}\right) \omega \bar{R}^{k} Q K$ in residual claims net of monitoring costs. In equilibrium, the lender earns an expected return equal to the safe rate $R$ implying

$$
\left(\int_{0}^{\bar{\omega}} \omega f(\omega) d \omega+\bar{\omega} \int_{\bar{\omega}}^{\infty} f(\omega) d \omega-\mu_{b} \int_{0}^{\bar{\omega}} \omega f(\omega) d \omega\right) \bar{R}^{k} Q K=R(Q K-N) .
$$

\footnotetext{
${ }^{37}$ To be consistent with the notation used in section 3.3.1, we are implicitly defining $R^{k}$ as
}

$$
R^{k}=\omega \bar{R}^{k}
$$


The optimal contract maximizes the payoff to the entrepreneur subject to the lender earning the required rate of return:

$$
\max _{K, \bar{\omega}}\left(\int_{\bar{\omega}}^{\infty} \omega f(\omega) d \omega\right) \bar{R}^{k} Q K
$$

subject to equation (43).

Given constant returns to scale, the cutoff $\bar{\omega}$ determines the division of expected gross profits $\bar{R}^{k} Q K$ between borrower and lender. We define $\Gamma(\bar{\omega})$ as the expected gross share of profits going to the lender:

$$
\Gamma(\bar{\omega}) \equiv \int_{0}^{\bar{\omega}} \omega f(\omega) d \omega+\bar{\omega} \int_{\bar{\omega}}^{\infty} f(\omega) d \omega .
$$

We similarly define $\mu_{b} G(\bar{\omega})$ as the expected monitoring costs:

$$
\mu_{b} G(\bar{\omega}) \equiv \mu_{b} \int_{0}^{\bar{\omega}} \omega f(\omega) d \omega
$$

The net share of profits going to the lender is $\Gamma(\bar{\omega})-\mu_{b} G(\bar{\omega})$, and the share going to the entrepreneur is $1-\Gamma(\bar{\omega})$, where by construction $\Gamma(\bar{\omega})$ satisfies $0 \leq \Gamma(\bar{\omega}) \leq 1$.

Under the assumption that $\ln (\omega) \sim N\left(-(1 / 2) \sigma^{2}, \sigma^{2}\right)$ we have

$$
\Gamma(\bar{\omega})=\Phi(z-\sigma)+\bar{\omega}[1-\Phi(z)]
$$

and

$$
\Gamma(\bar{\omega})-\mu G(\bar{\omega})=(1-\mu) \Phi(z-\sigma)+\bar{\omega}[1-\Phi(z)] .
$$

where $\Phi(\cdot)$ is the c.d.f. of the standard normal and $z$ is related to $\bar{\omega}$ through $z \equiv(\ln (\bar{\omega})+$ $\left.0.5 \sigma^{2}\right) / \sigma$.

In steady-state, the contracting problem may be written as:

$$
\max _{K, \bar{\omega}}(1-\Gamma(\bar{\omega})) \bar{R}^{k} Q K
$$

subject to:

$$
[\Gamma(\bar{\omega})-\mu G(\bar{\omega})] \bar{R}^{k} Q K=R(Q K-N)
$$

Let $s=\frac{\bar{R}^{k}}{R}$ denote the premium on external funds and $k=\frac{Q K}{N}$ the steady-state ratio of capital to net worth. The first-order conditions for the contracting problem imply that

$$
s(\bar{\omega}) \equiv \frac{\lambda(\bar{\omega})}{\Psi(\bar{\omega})}
$$




$$
k(\bar{\omega}) \equiv \frac{\Psi(\bar{\omega})}{1-\Gamma(\bar{\omega})}
$$

where

$$
\lambda(\bar{\omega})=\frac{\Gamma^{\prime}(\bar{\omega})}{\Gamma^{\prime}(\bar{\omega})-\mu_{b} G^{\prime}(\bar{\omega})} .
$$

denotes the Lagrange multiplier on the constraint that lenders earn their required rate of return in expectation and

$$
\Psi(\bar{\omega})=1-\Gamma(\bar{\omega})+\lambda(\bar{\omega})[\Gamma(\bar{\omega})-\mu G(\bar{\omega})]
$$

Equations (44) and (45) provide an implicit relationship between capital expenditures per unit of net worth $k(\bar{\omega})$ and the premium on external funds that is the basis for equation (22)

To complete our derivation of the steady-state contract, we need to consider the steadystate determinants of the return on capital and the net worth accumulation equation. The steady-state return on capital is determined according to the standard Jorgensonian formula:

$$
\frac{1}{\mu} \alpha \frac{Y}{K}=\bar{R}^{k}-(1-\delta)
$$

The steady-state net worth accumulation satisfies

$$
\frac{N}{K}=\phi \frac{V}{K}+\frac{1}{\mu} \Omega \frac{Y}{K}
$$

where

$$
\frac{V}{K}=(1-\Gamma(\bar{\omega})) \bar{R}^{k}
$$

is the return on equity and $\frac{1}{\mu} \Omega \frac{Y}{K}$ are total managerial labor earnings normalized by the capital stock. Combining equations (46), (47), and (48), we obtain

$$
\frac{\bar{R}^{k}}{R}-\frac{(1-\delta)}{R}=\frac{\alpha}{\Omega}\left(\frac{1}{R} \frac{N}{K}-\phi(1-\Gamma(\bar{\omega})) \frac{\bar{R}^{k}}{R}\right) .
$$

Applying equations (44) and (45) we have

$$
s(\bar{\omega})-(1-\delta) \beta=\frac{\alpha}{\Omega}\left(\beta k(\bar{\omega})^{-1}-\phi(1-\Gamma(\bar{\omega})) s(\bar{\omega})\right) .
$$

Given structural parameters $\left(\Omega, \alpha, \mu, \beta, \sigma, \phi, \mu_{b}\right)$, it is straightforward to solve equation (49) for the cutoff $\bar{\omega}$ using numerical techniques. Once $\bar{\omega}$ is obtained, we can compute the implied premium $s(\bar{\omega})$ and the implied capital-net worth ratio $k(\bar{\omega})$ using equations (44) and (45). The the rest of the model's steady-state can then be computed in a standard fashion. 
In our calibration exercise, we set $\sigma=0.28, \mu_{b}=0.12,1-\phi=0.0272, \alpha=0.5, \mu=$ $1.2, \Omega=0.01$. These values imply a 6 percent default rate, a 3.5 percent premium on external funds, and a ratio for $Q K / N=2.1$.

Having derived the steady-state of the model, we now consider log-linearizing the key financial equations. For notational ease during our computations, we eliminate the debt variable from equation (22) by noting that $B_{t+1} / P_{t}=Q_{t} K_{t+1}-N_{t+1}$. Accordingly, equation (22) can be written in log-linear form as:

$$
E_{t}\left\{\widehat{r}_{t+1}^{k}\right\}-\widehat{r}_{t}=-\frac{1}{v}\left[\widehat{n}_{t+1}-\left(\widehat{q}_{t}+\widehat{k}_{t+1}\right)\right]
$$

where

$$
v=\frac{\Psi^{\prime}(\bar{\omega})}{\Psi(\bar{\omega})}+\frac{\Gamma^{\prime}(\bar{\omega})}{1-\Gamma(\bar{\omega})}
$$

is the steady-state elasticity of $k$ with respect to $s$. This elasticity may be obtained by differentiating equations (44) and (45) with respect to $\bar{\omega}$ and evaluating these derivatives at the steady-state value of $\bar{\omega}$ implied by equation (49). 


\section{FIGURE 1}

Real GDP

(log, detrended)

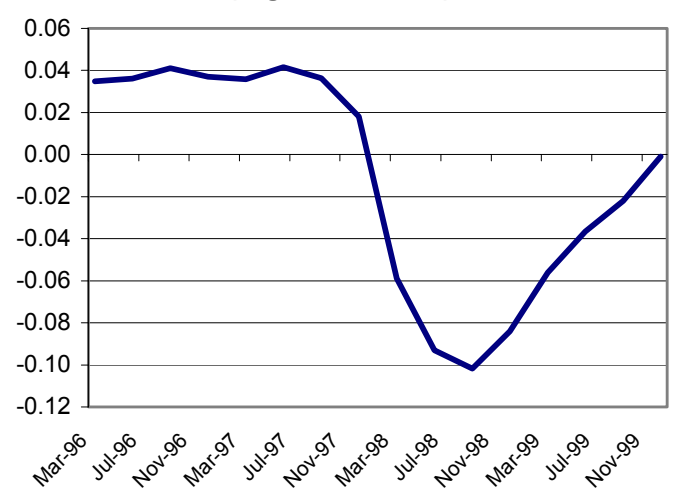

Total Employment

(log, detrended)

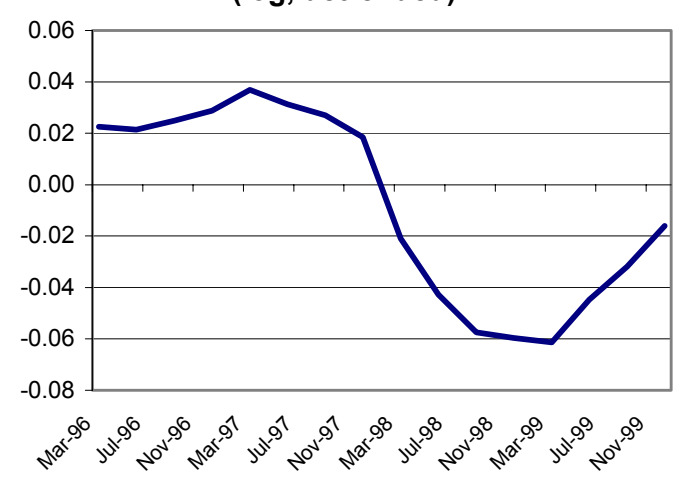

Real GDP per worker

(log, detrended)

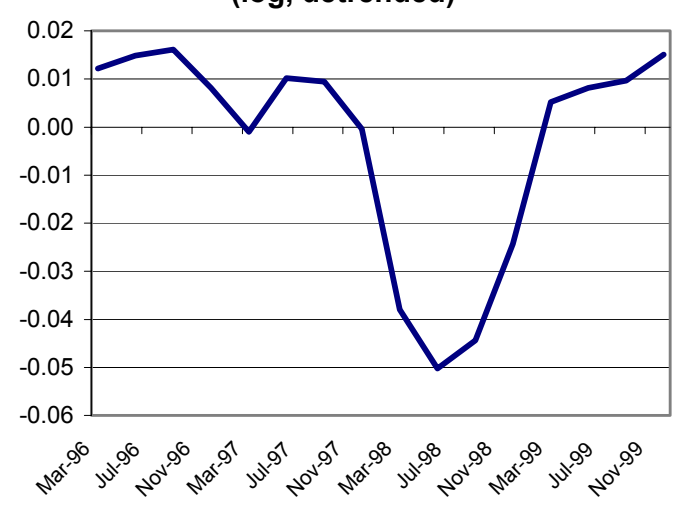

Real Gross Capital Formation (log, detrended)

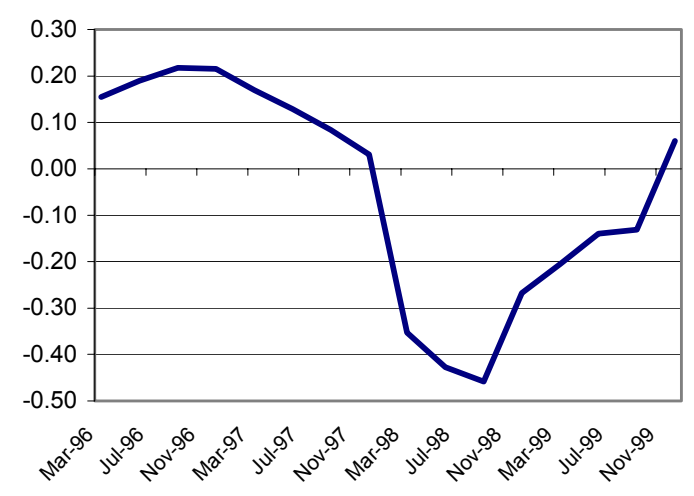

Real Consumption

(log, detrended)

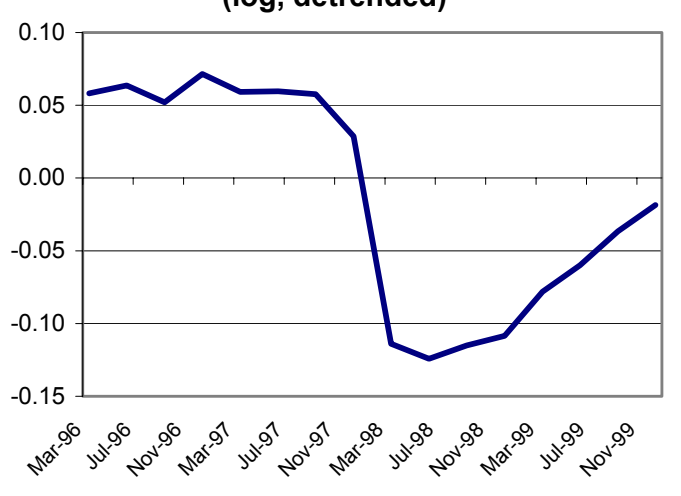

Electricity Consumption

(log, detrended)

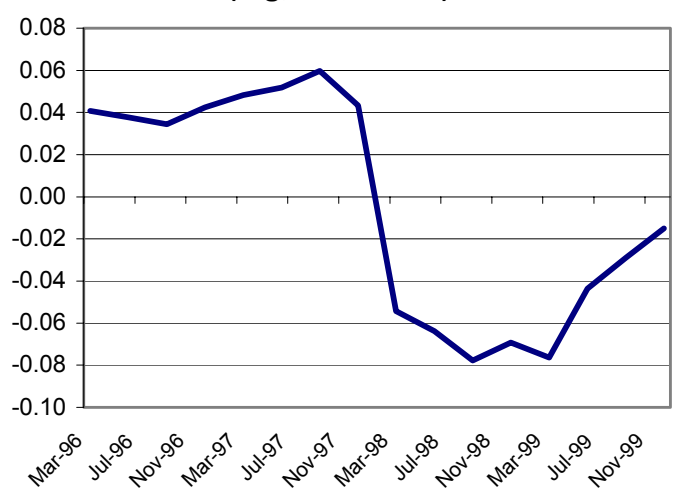


FIGURE 2

EMBI Global Korea (\% pa, daily)

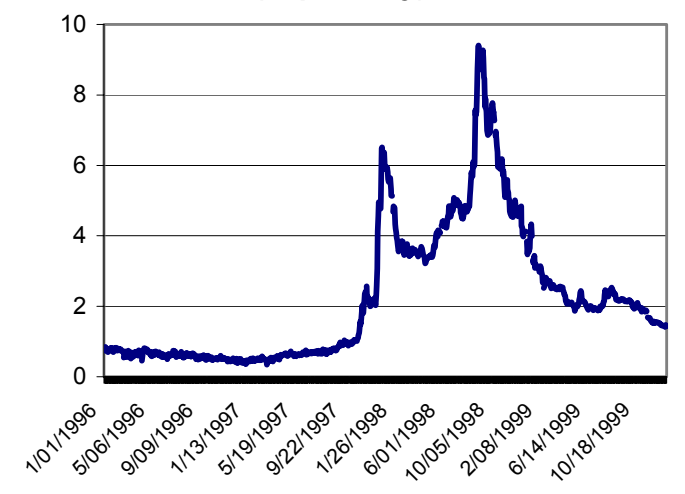

Call Rates, overnight

(\% pa, monthly average)

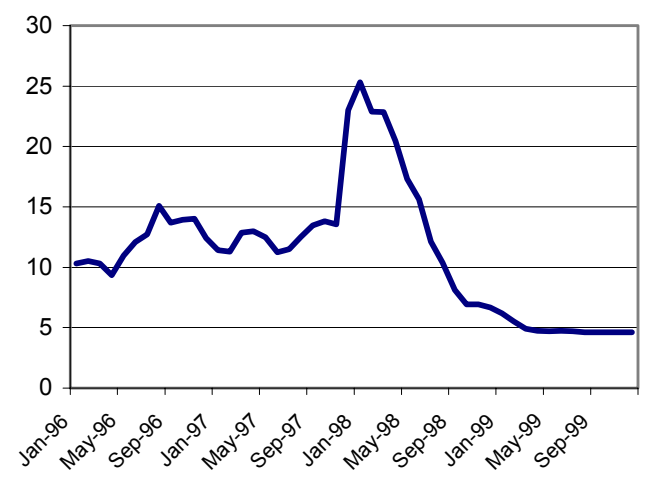

Korean Won to US Dollar (Monthly average)

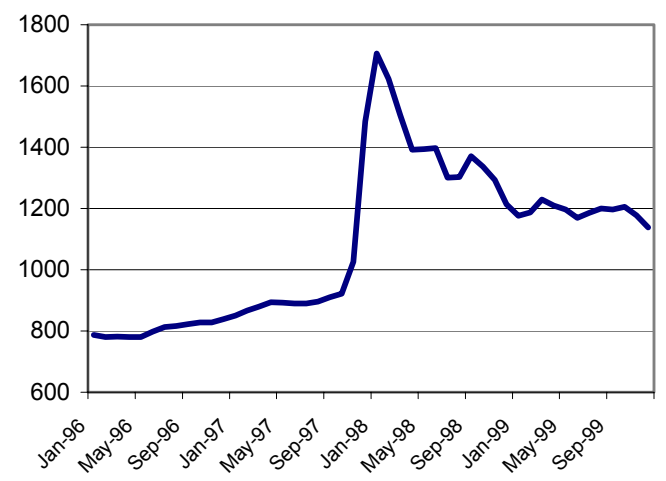

Spread, corporate-treasury bonds (\% pa, monthly average, 3 yr maturity)

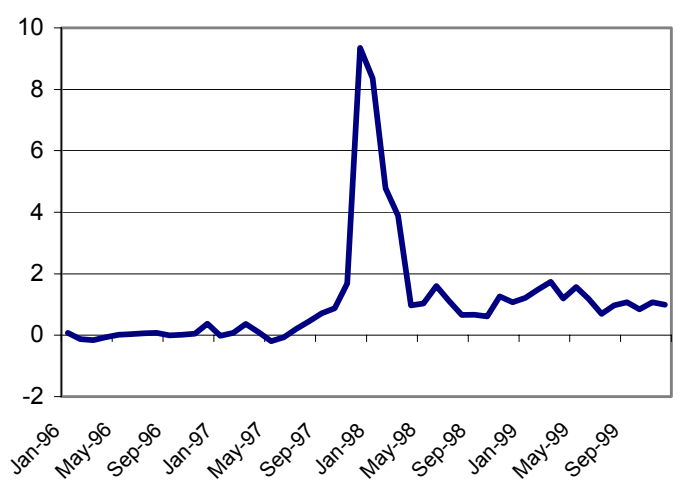

CPI Inflation (\%, quarterly, o-y-a)

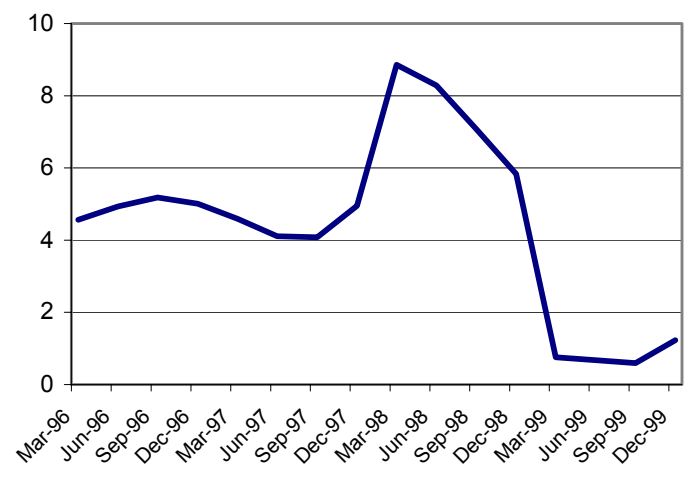

Korean Stock Exchange: KOSPI (monthly, 4/01/1980=100)

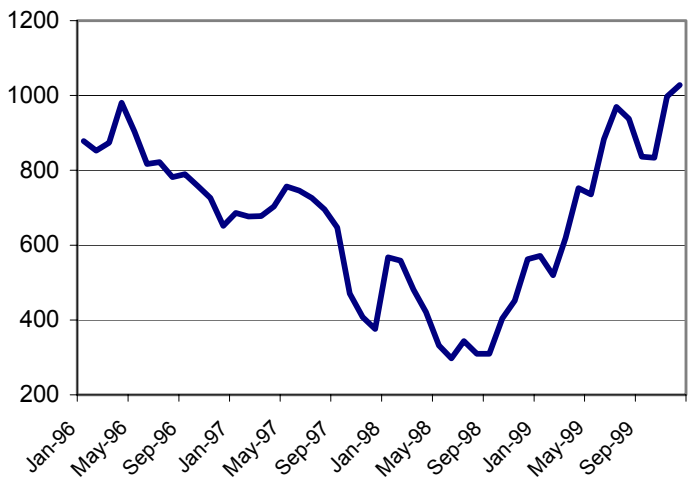

41 


\section{FIGURE 3}

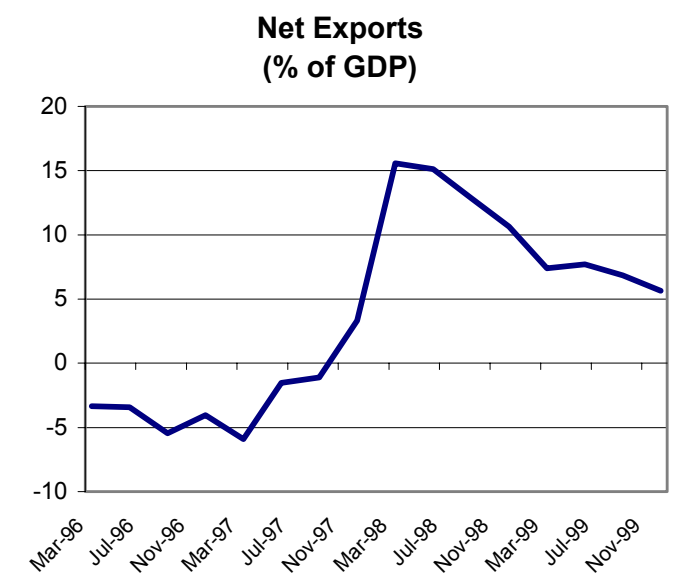

Trade-weighted Real Exchange Rate (log, detrended)

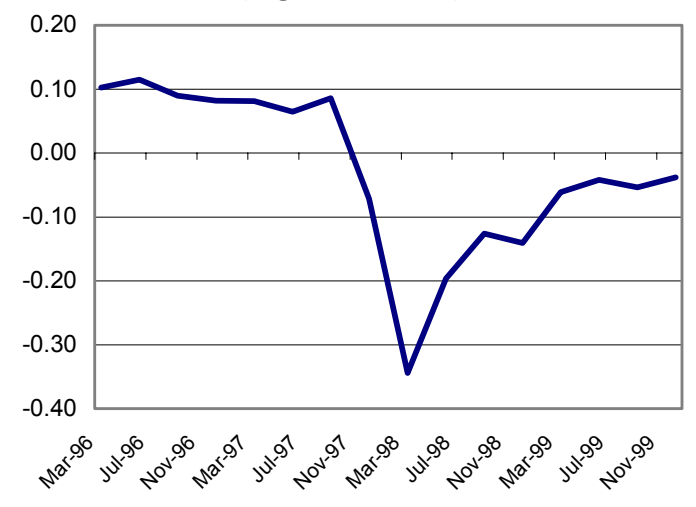

Real Exports

(log, detrended)

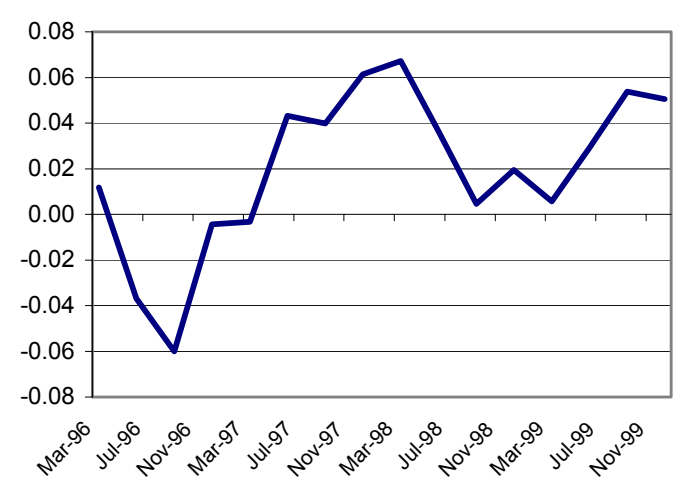

Real Imports

(log, detrended)

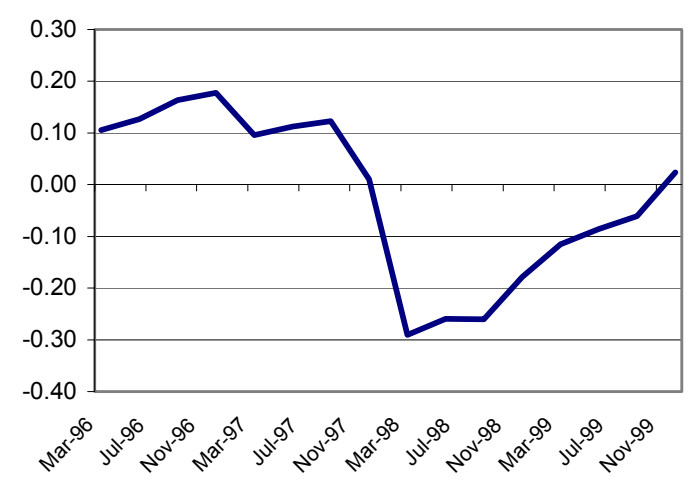


FIGURE 4A: COUNTRY RISK PREMIUM SHOCK

FIXED VS. FLEXIBLE EXCHANGE RATE

OUTPUT

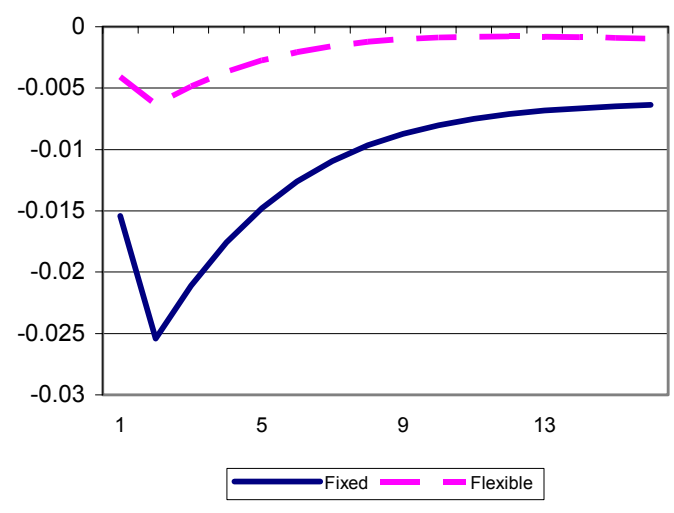

CAPITAL UTILIZATION RATE

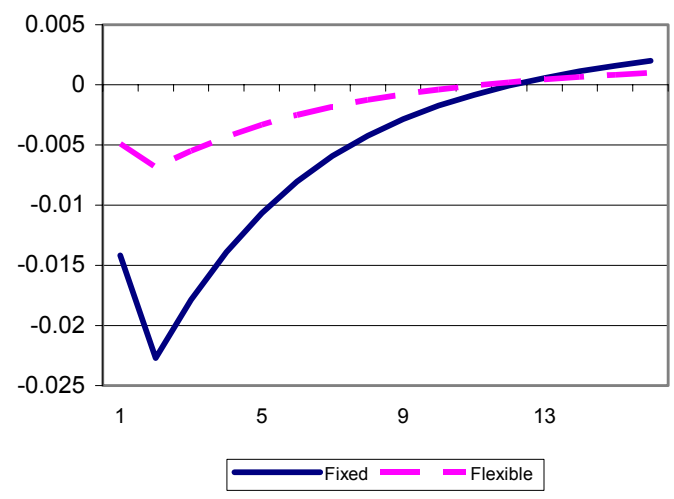

HOUSEHOLD CONSUMPTION

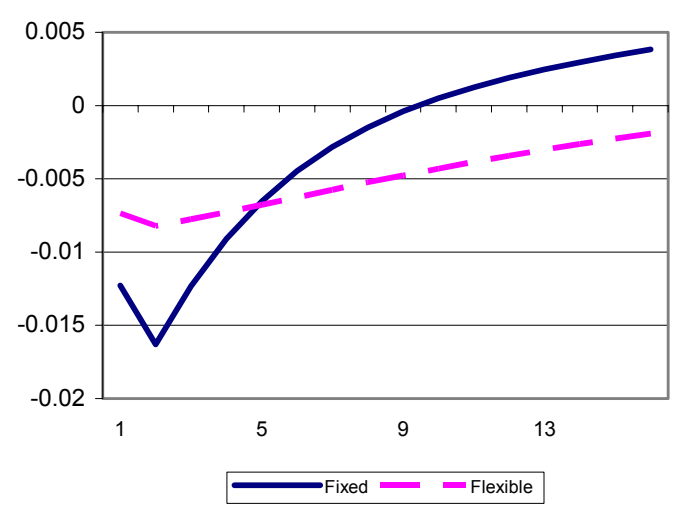

INVESTMENT

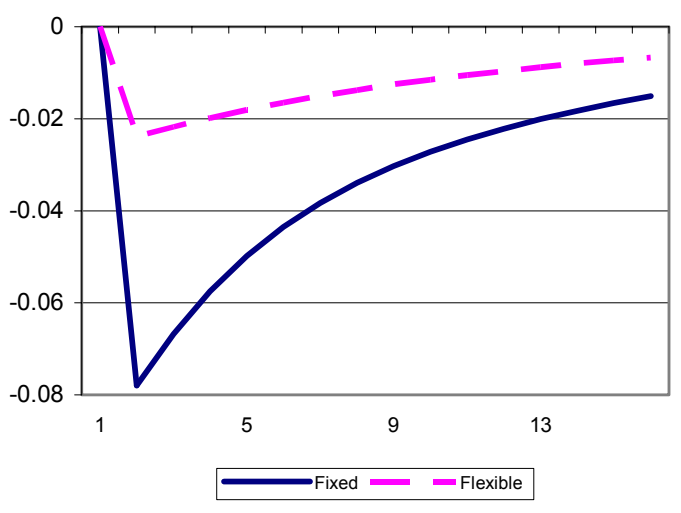

LABOR PRODUCTIVITY

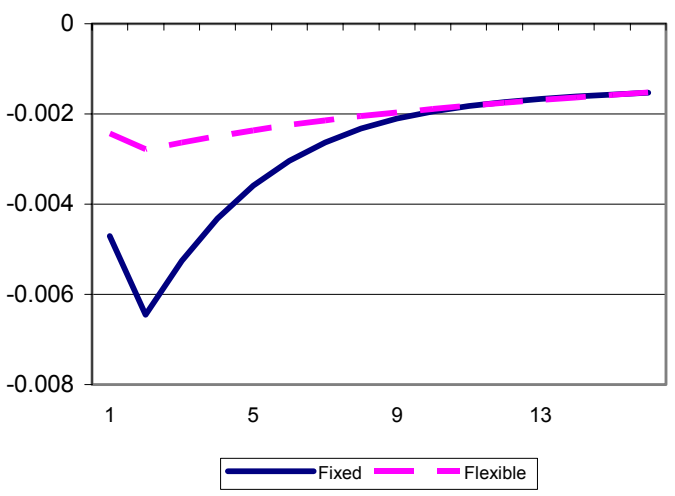

NET EXPORTS

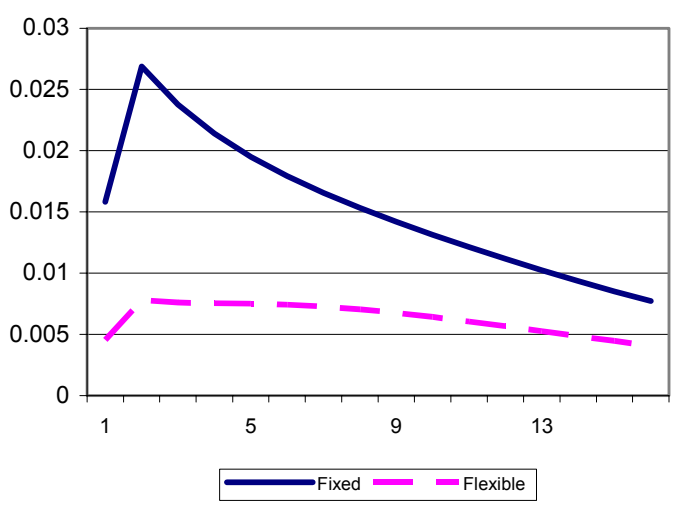


FIGURE 4B: COUNTRY RISK PREMIUM SHOCK

FIXED VS. FLEXIBLE EXCHANGE RATE (cont'd)

NOMINAL INTEREST RATE

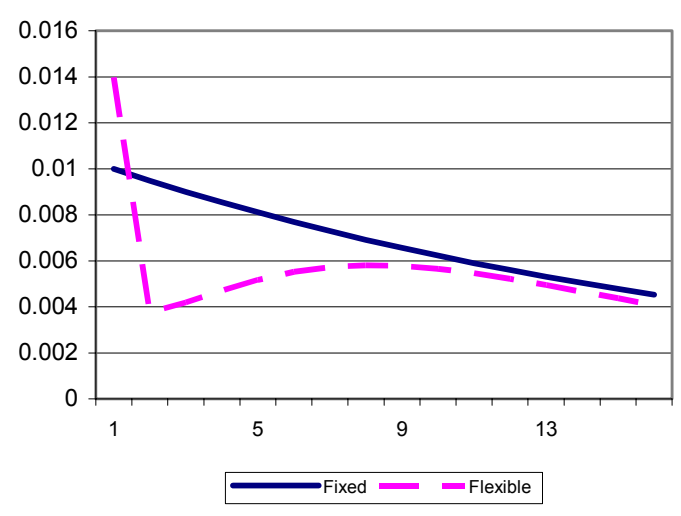

CPI INFLATION

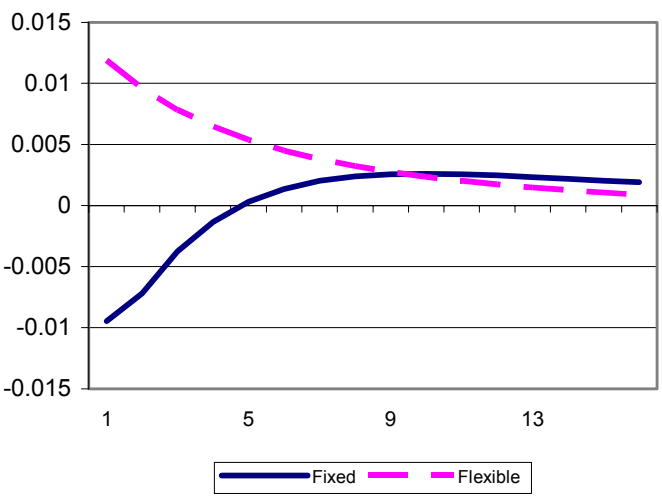

NOMINAL EXCHANGE RATE

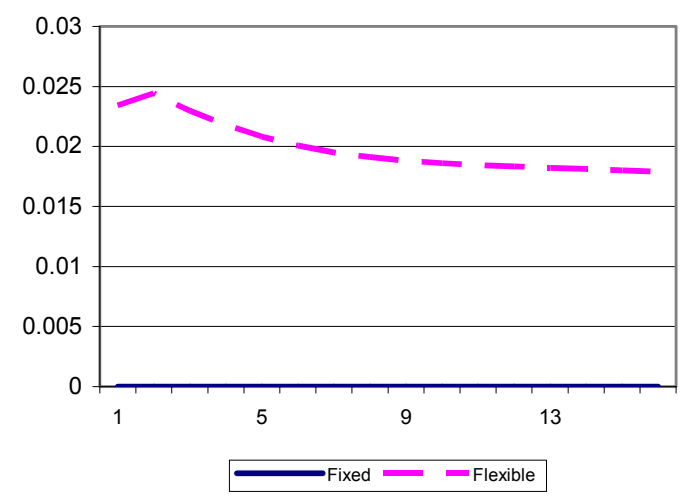

REAL INTEREST RATE

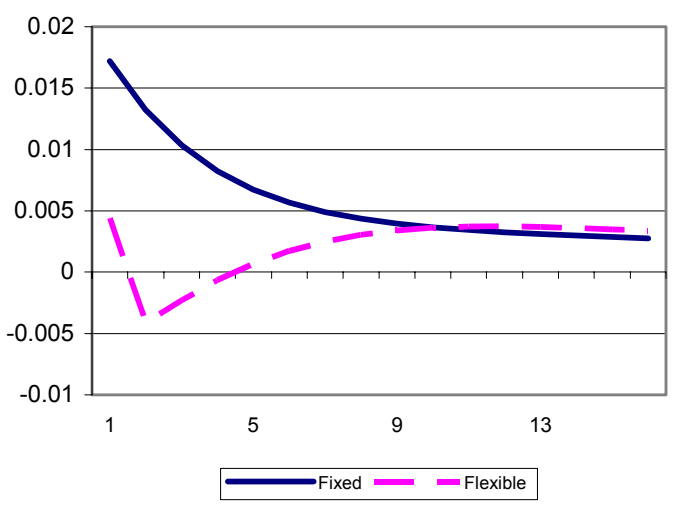

EXTERNAL FINANCE PREMIUM

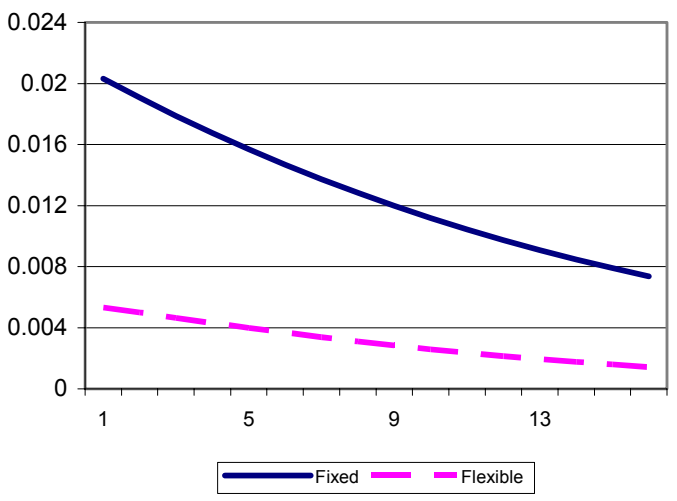

REAL EXCHANGE RATE

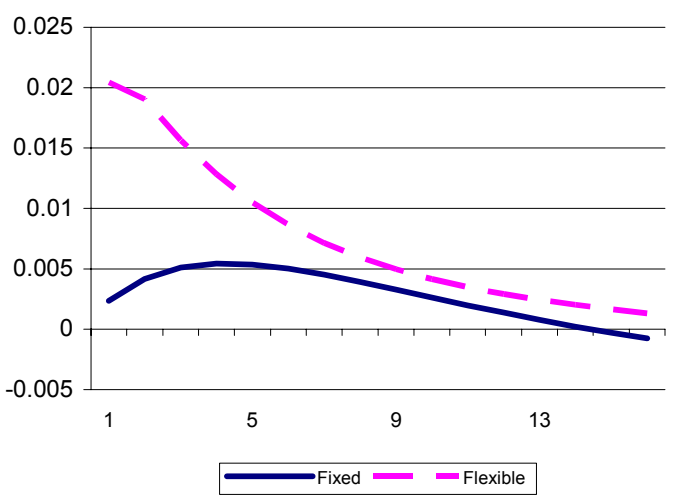


FIGURE 5: COUNTRY RISK PREMIUM SHOCK

WITH VS. WITHOUT FINANCIAL ACCELERATOR

OUTPUT: FIXED RATES

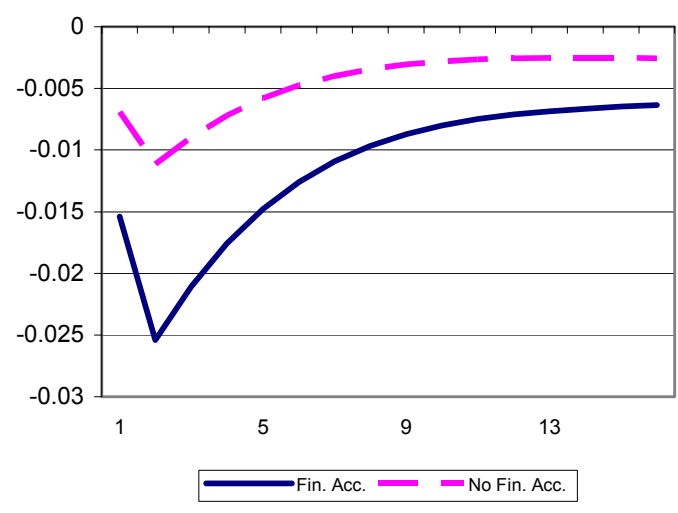

INVESTMENT: FIXED RATES

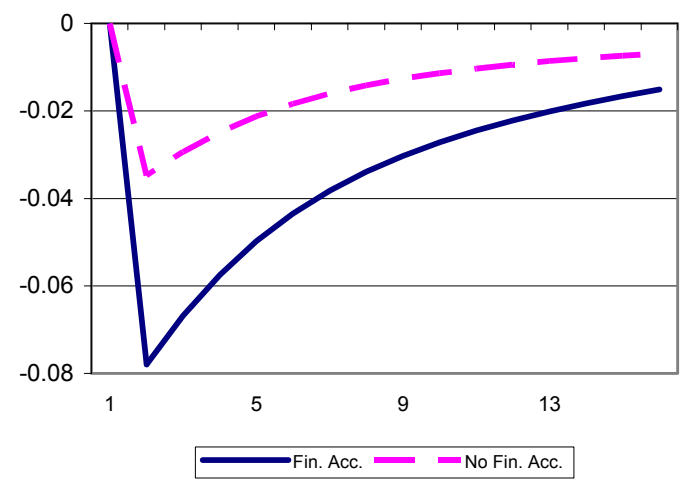

OUTPUT: FLEXIBLE RATES

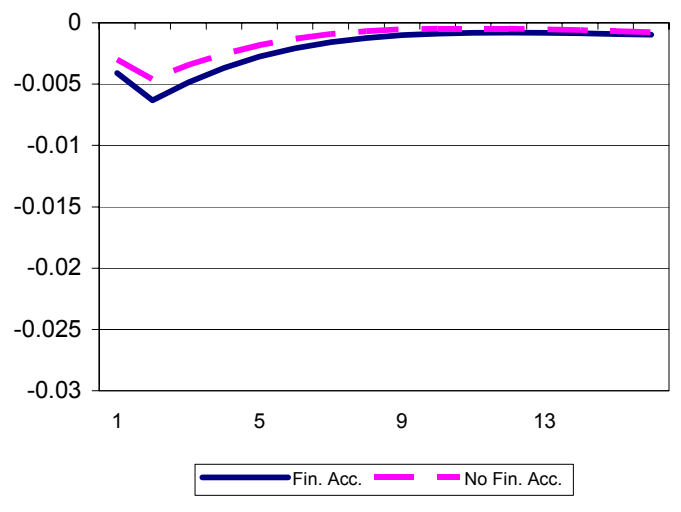

INVESTMENT: FLEXIBLE RATES

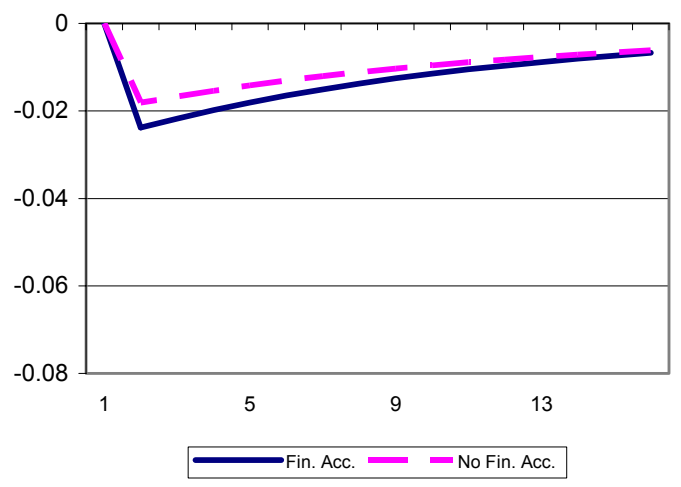




\section{FIGURE 6A}

\section{KOREAN CRISIS EXPERIMENT}

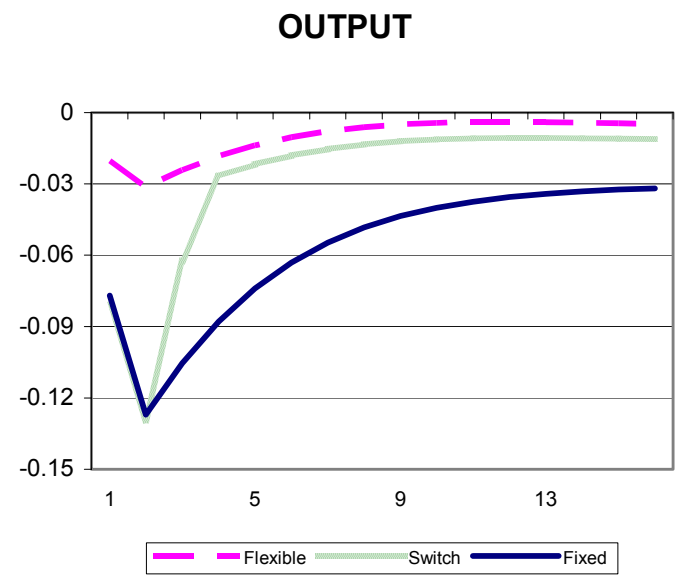

CAPITAL UTILIZATION RATE

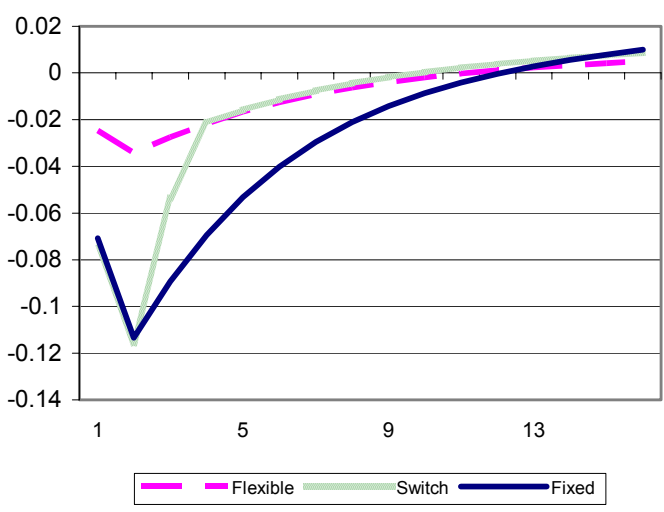

HOUSEHOLD CONSUMPTION

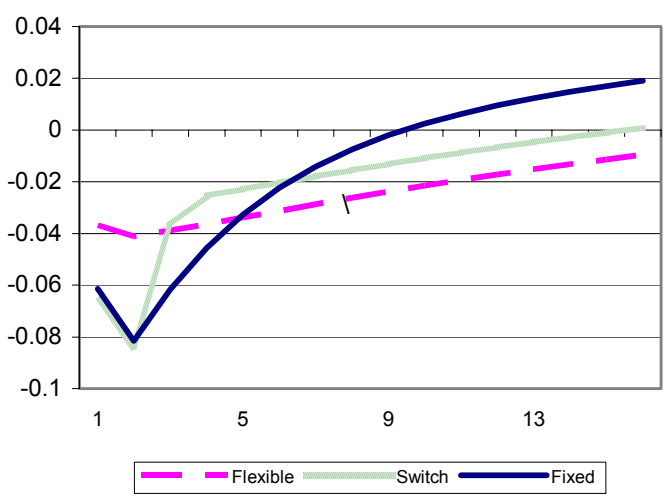

INVESTMENT

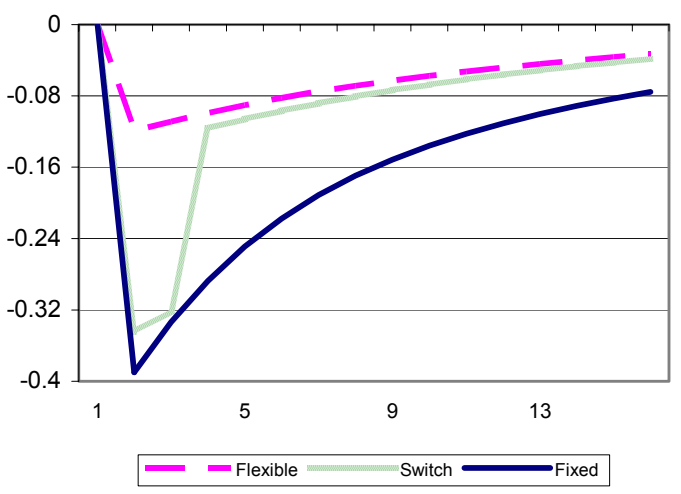

LABOR PRODUCTIVITY

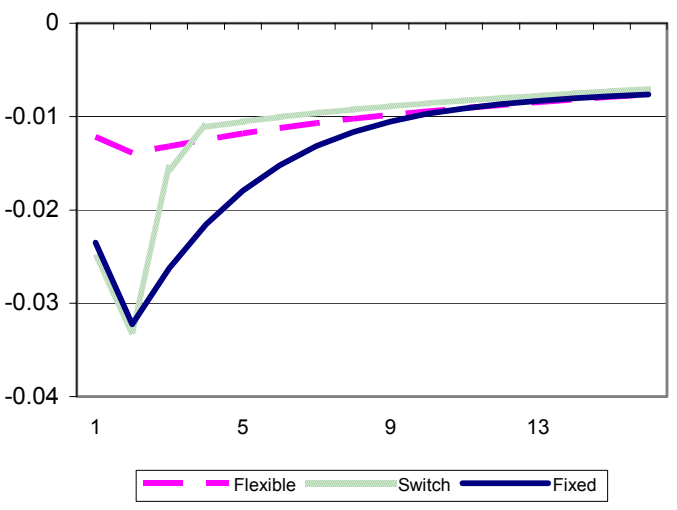

NET EXPORTS

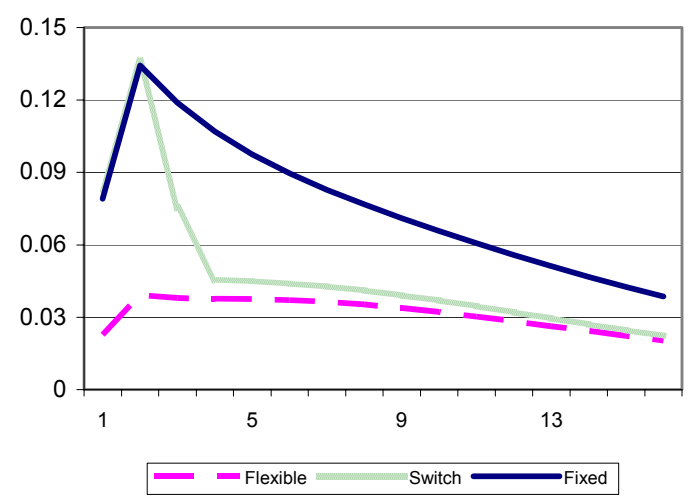




\section{FIGURE 6B}

KOREAN CRISIS EXPERIMENT (cont'd)

NOMINAL INTEREST RATE

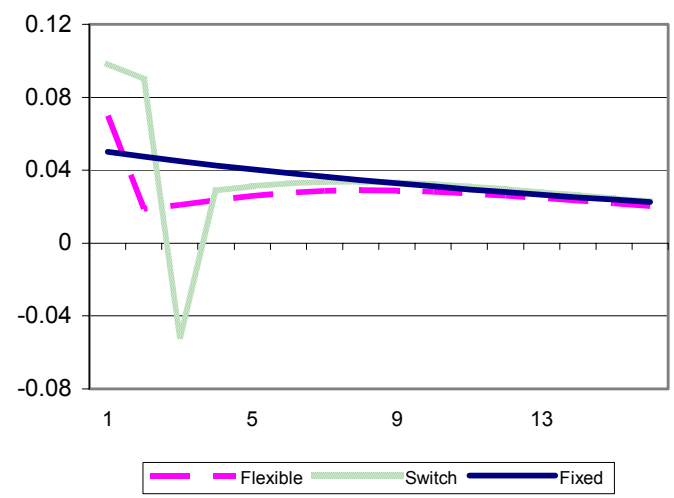

CPI INFLATION

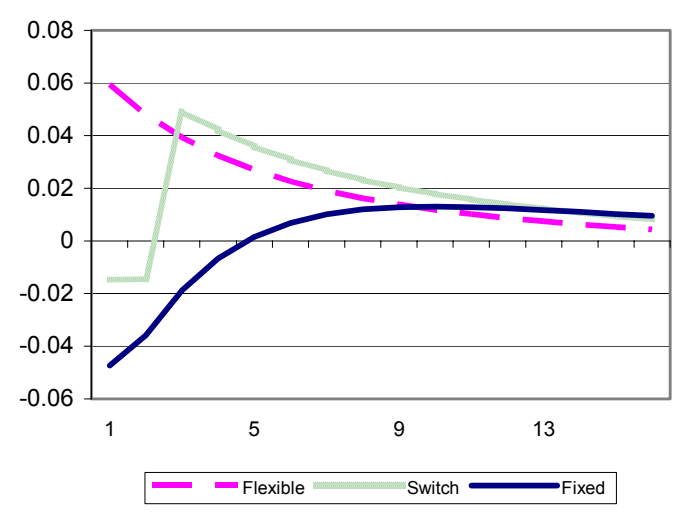

NOMINAL EXCHANGE RATE

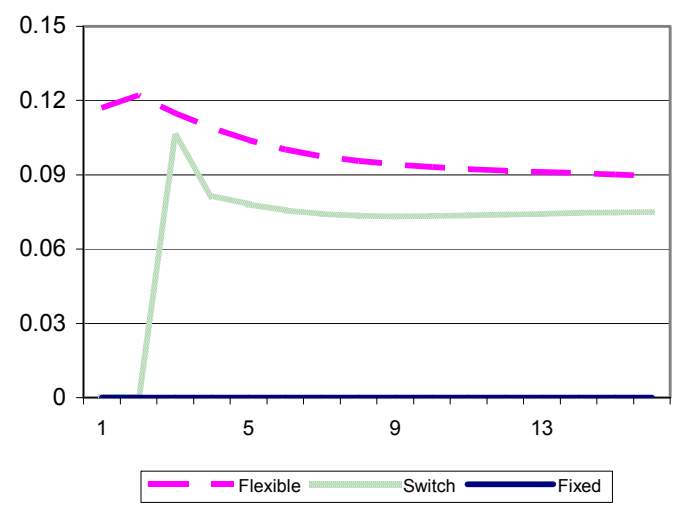

REAL INTEREST RATE

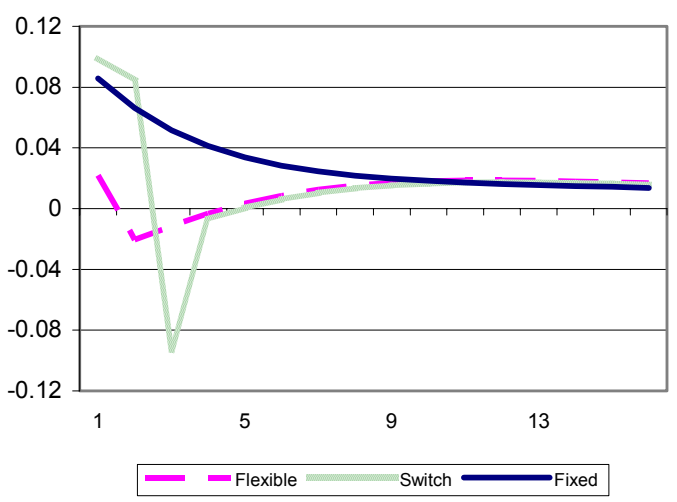

EXTERNAL FINANCE PREMIUM

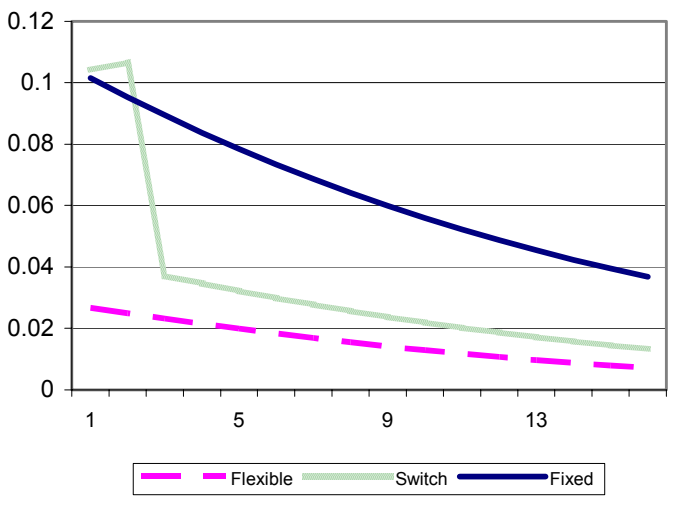

REAL EXCHANGE RATE

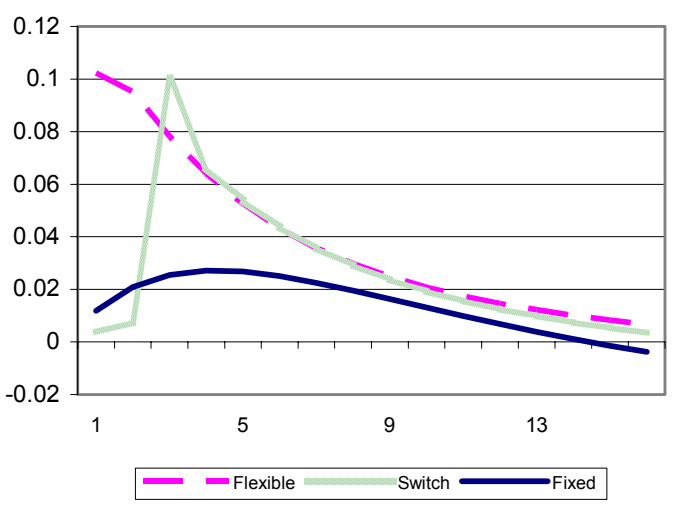


FIGURE 7: COUNTRY RISK PREMIUM SHOCK

DOMESTIC VS. FOREIGN DENOMINATED DEBT

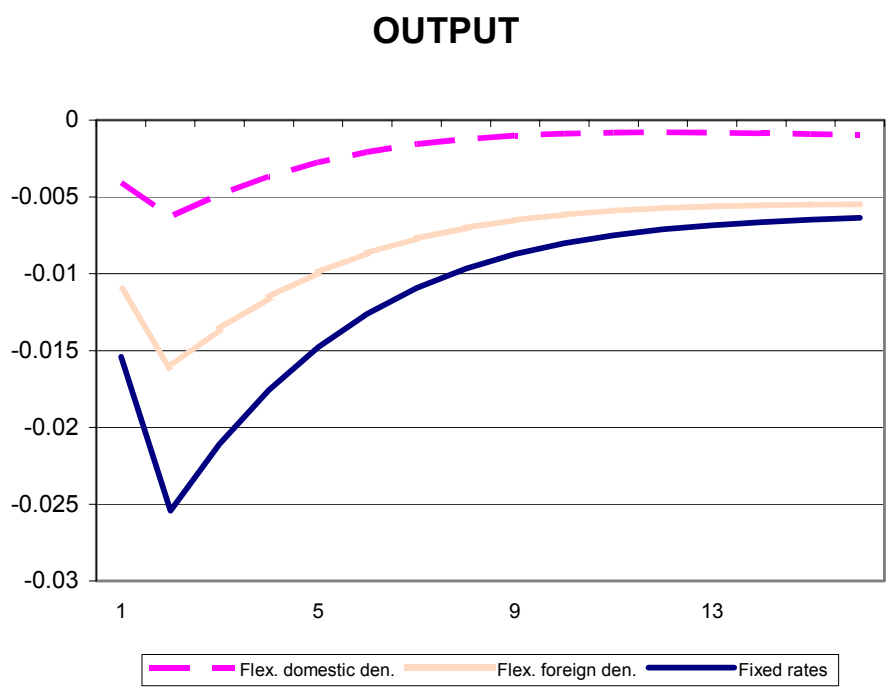

INVESTMENT

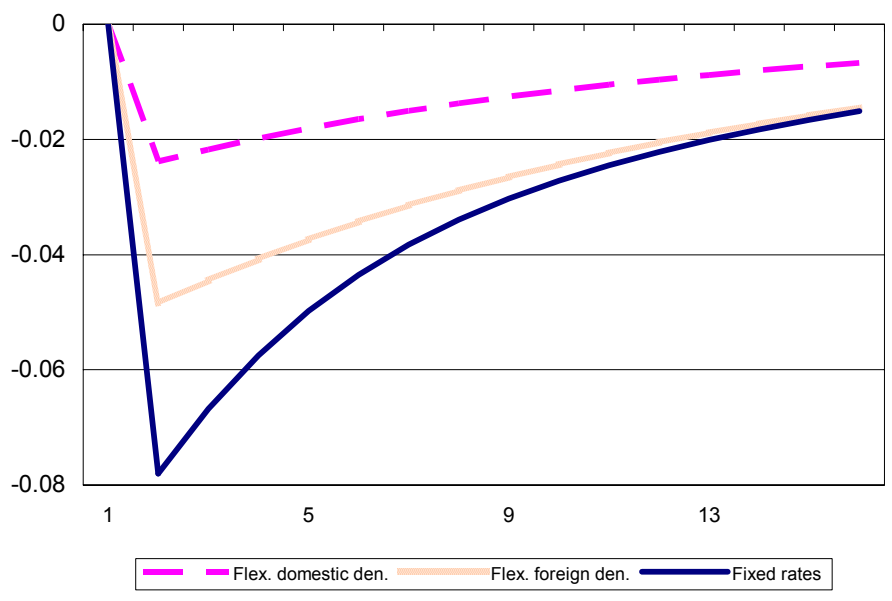

